\title{
Políticas geo-estratégicas y misionales en el sur de Filipinas: el caso de Mindanao y Joló (siglo XVIII)*
}

\author{
por
}

\author{
Alexandre Coello de la Rosa ${ }^{1}$ \\ Universitat Pompeu Fabra (UPF-GRIMSE)
}

\begin{abstract}
Este ensayo analiza las políticas geo-estratégicas y misionales que impulsaron la defensa de las posiciones españolas en el sur de las islas Filipinas. Mientras que los agustinos recoletos, encargados de la evangelización de las islas Calamianes, denunciaron los continuos ataques de los «moros» al rey y al Consejo de Indias, y propusieron alternativas al restablecimiento del presidio de Zamboanga, los jesuitas querían mantener el presidio a toda costa. Pero además, este ensayo presenta la propuesta reformista de Juan Joseph Calvo, SJ, procurador general de la Compañía de Jesús en las cortes de Roma y Madrid, cuyo modelo efectivo de colonización de la isla de Mindanao consistía, por un lado, en desmontar gradualmente el presidio de Guam, en las islas Marianas, trasladando a sus misioneros al sur de Filipinas y, por el otro, proponer un modelo económico de explotación de la canela que, aunque fracasó, pretendía promover su poblamiento y fortalecer la presencia española en la gran isla del sur.
\end{abstract}

Palabras ClaVE: Mindanao; Joló; siglo XVIII; jesuitas; agustinos recoletos; Manila.

Cómo Citar este artículo / Citation: Coello de la Rosa, Alexandre, "Políticas geo-estratégicas y misionales en el sur de Filipinas: el caso de Mindanao y Joló (siglo XVIII)", Revista de Indias, LXXIX/277 (Madrid, 2019): 729-763. https://doi.org/10.3989/revindias.2019.021.

* Este artículo ha sido elaborado en el marco del proyecto "Dentro y fuera: Cambio institucional e integración social y cultural en el imperio español moderno y contemporáneo, 1550-1950 (una perspectiva comparada de larga duración)", financiado por el Ministerio de Economía y Competitividad (FEDER/MINECO), Ref., HAR2015-68183-P. Agradezco a la Fundación BBVA la ayuda financiera para haber podido llevar a cabo este trabajo ("Investigadores y creadores culturales, 2016").

1 alex.coello@upf.edu, ORCID iD: http://orcid.org/0000-0001-5079-6180. 
A principios del siglo XVII las islas de Mindanao, Joló e islas adyacentes eran dos puntos estratégicos desde los cuales se podía acceder al archipiélago de las Molucas y al resto de las islas que hoy día forman Indonesia². En 1596 llegó a Manila el padre Francisco de Vera, provincial de la Compañía de Jesús, a quien el sevillano don Francisco Tello de Guzmán II (1596-1602), gobernador y capitán general de las Filipinas (1596-1602), había elegido como su confesor. Desde entonces, los provinciales de la Compañía miraron siempre aquellas islas «como a cosa suya», y no escatimaron esfuerzos para la con-

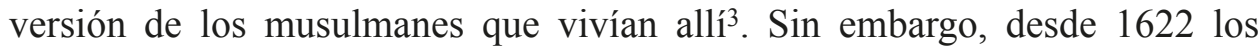
agustinos recoletos operaban en la provincia de Calamianes y en el nordeste de Mindanao, extendiéndose a lo largo de los poblados de Butúan a Cateel (Davao Oriental) hasta Caraga, rivalizando con los jesuitas en la evangelización del Mar de Joló4.

Asimismo, los intereses británicos y holandeses se habían incrementado en el sur de Filipinas, temiéndose un ataque militar en la región ${ }^{5}$. Para prevenir una potencial invasión extranjera, las autoridades españolas decidieron restablecer el presidio de [Nuestra Señora del Pilar de Zaragoza] Zamboanga en $1719^{6}$. Este hecho confirmaba, según Isaac Donoso, el valor estratégico del presidio como bastión militar en el sur de Mindanao ${ }^{7}$. Frente a la satisfacción de los jesuitas, los agustinos recoletos protestaron enérgicamente, proponien-

2 Colín-Pastells, 1904.

3 Combés, 1897: 94 y ss.

4 Fernández, 1979: 25. El 6 de febrero de 1624, el gobernador general de las Filipinas, don Alonso Fajardo de Tenza (1618-24), dividió la isla de Mindanao en dos áreas de influencia: las regiones comprendidas al nordeste de una línea imaginaria que comprendía desde el cabo Suluan hasta el de San Agustín fueron adjudicadas a los agustinos recoletos, mientras que las regiones emplazadas al sudoeste de esa misma línea corresponderían a los jesuitas. El 12 de julio de 1628 el gobernador Juan Niño de Tavora (1626-32) confirmó esta división. Pero como señala Martínez Cuesta, este acuerdo no estuvo exento de tensiones entre ambas órdenes (Martínez Cuesta, 1995: 378-380).

5 Laarhoven, 1989: 177-181.

6 Barrio, 2012: 66-67. En 1665 el gobernador Sabiniano Manrique de Lara (1653-1663) había decidido desmantelar el presidio de Zamboanga, abandonando a la grey cristiana a su suerte. Los jesuitas, encabezados por el padre Francisco Combés (1620-1665), protestaron enérgicamente ante lo que consideraron un atentando contra su política de expansión evangelizadora en el sur de Filipinas (Murillo Velarde, 1749: 276v). Para el bibliófilo Wenceslao E. Retana, el objetivo del padre Francisco Combés en su Historia de Mindanao y Joló (Madrid, 1667), no había sido otro que mostrar su desacuerdo por el desalojo de las fortalezas del sur de Mindanao y «dar a conocer cumplidamente cuánto importaba a España la dominación de Mindanao» (Retana, 1897: xviii).

7 Donoso, 2012: 208. Véase también Luengo, 2017: 740-743. 
do alternativas de defensa y fortificación al rey y al Consejo de Indias para las misiones que administraban en la provincia de Calamianes ${ }^{8}$.

Este ensayo analiza las tensiones políticas, geo-estratégicas y misionales que impulsaron la defensa de las posiciones españolas en el sur de las Filipinas. Asimismo, este estudio pretende demostrar que los procuradores generales de la Compañía de Jesús presentaron un modelo efectivo de conquista y evangelización que consistía, por un lado, en desmontar gradualmente el presidio de las islas Marianas, donde los nativos chamorros escaseaban, transfiriendo a sus misioneros al archipiélago filipino, y en particular, a las islas de Mindanao y Joló. Por el otro, propusieron un modelo económico de explotación de la canela, cuyo fin último consistía en promover el poblamiento y fortalecer la presencia española en la gran isla «mora». Como veremos a continuación, el proyecto del procurador Juan Joseph Calvo fracasó por varias razones: una, por la renuencia de la Corona a perjudicar los intereses de los vecinos de Manila; y dos, por la importancia geo-estratégica de las Marianas, que impidió reducir la presencia militar del presidio ni a permitir que los jesuitas abandonaran el archipiélago9.

\section{En defensa de la provincia de Calamianes}

En 1718, un año antes del asesinato del gobernador general de Filipinas, don Fernando Manuel de Bustillo Bustamante y Rueda (1717-19) ${ }^{10}$, el sultán de Jolón ${ }^{11}$ cedió una parte del territorio que poseía en la isla de Palawan (o Paragua), donde se construyó el presidio de Labo, cerca del pueblo de Balaba

8 En 1622, fray Pedro de Arce, OSA, obispo del Santísimo Nombre de Jesús de Cebú y gobernador interino del arzobispado de Manila (1613-42), confió la administración espiritual de Mindanao, así como las islas de Palawan y Cuyo, a los agustinos recoletos (Martínez Cuesta, 1995: 365, 378-393).

9 El 31 de julio de 1748, fray Juan de Arrechederra, obispo electo de Nueva Segovia y gobernador interino de las Filipinas (1745-50), escribió a Fernando VI comunicándole las diligencias practicadas en cumplimiento de la Real Cédula de 1741 para el restablecimiento y conservación de las Marianas (Arxiu Històric de la Companyia de Jesús a Catalunya, Barcelona (en adelante, AHCJC), FILPAS-093, doc. 27, f. 257).

10 Noticias de lo sucedido en la ciudad de Manila, desde el primero día de Octubre, hasta el 11 de dicho mes del año 1719, Herederos de Thomas López de Haro en calle de Génova, s.n. Biblioteca de la Universidad de Sevilla, referncia A. 109/036(57), 1720, ff. 1r-4v. Véase también Fernández, 1979: 133-135. De la Costa, 1989: 581.

11 Según Evangelista, «by the middle of the 15th century, Sherif Abu Bakr founded the Sultanate of Sulu, indicating the growth of Islamic consciousness among the people of Sulu (...). From Sulu, Islam went to the Mindanao area» (Evangelista, 1988: 22). 
(o Balabac), en su extremo meridional, con el objetivo de controlar las costas del norte de Borneo ${ }^{12}$. Sin embargo, en 1720, en tiempos del gobierno interino del arzobispo jeromita fray Francisco de la Cuesta (1658-1724), la Junta General de Guerra y Hacienda de Manila decidió abandonarlo, concentrando sus fuerzas en la isla de Zamboanga ${ }^{13}$. Esta decisión, como veremos, fue duramente criticada por el capitán Juan Antonio de la Torre, que había servido varios años en la provincia de Calamianes, y por los agustinos recoletos, cuyas misiones quedaron a merced de los «joloes, borneyes, tidores, camucones, macazares y mindanaos». A consecuencia del cierre del presidio de Labo, el vicario provincial de los recoletos, fray Benito de San Pablo, lamentaba que la provincia de Calamianes hubiera caído en manos de los piratas joloanos $^{14}$. Entre 1720 y 1750 murieron trece religiosos a manos de las incursiones «moras», abriendo «un nuevo período de terror, desolación y muerte» ${ }^{15}$.

En 1736, el procurador y comisario general de los agustinos recoletos, fray Francisco de la Encarnación (i-1749), OAR, dirigió un Memorial al rey Felipe V (1700-46) el que condenaba los continuas invasiones que los «moros» ${ }^{16}$ venían efectuando desde 1720 sobre las islas Calamianes, quemando conventos, iglesias y pueblos, robando los objetos sagrados, asesinando a los frailes doctrineros y esclavizando a los vasallos del rey ${ }^{17}$. En dicho Memorial, escrito a fines de junio de 1735 en la corte de Madrid, el ex provincial recoleto informaba de la cruel muerte de su cofrade, el padre fray Manuel de Jesús María, al cual ejecutaron cruelmente en 1720, «cortándole las narices, orejas, manos y pies, y poniendo pendiente el cadáver con una soga en lo más alto del pórtico de la iglesia» ${ }^{18}$. Además denunciaba la profanación de las imáge-

12 Barrio, 2012: 56, 62.

13 Memorial de Fray Francisco de la Encarnación, ORSA, al Rey, 1736, Archivo General de Indias, Sevilla (AGI), Filipinas, 227, ff. 13v-14r. Véase también la carta del arzobispo gobernador de Manila, fray Francisco de la Cuesta, al rey Felipe V, con fecha en Manila, 14 de julio de 1721, dando cuenta con testimonio de «haberse continuado las providencias sobre el restablecimiento del presidio de Zamboanga y quedar libre del sitio que le pusieron los reyes de Joló y Mindanao» (AHCJC, FILPAS-078, 1721, f. 98r). Véase también VV.AA., 1989: 544. Barrio, 2012: 56-57. Luengo, 2017: 741.

14 Barrio, 2012: 76-77.

15 Martínez Cuesta, 1995: 538.

16 Para una definición del concepto de «moro» y su aplicación a las Filipinas, véase Donoso, 2011: 376-378.

17 Carta del Provincial de los Agustinos Descalzos, fray Joseph de la Concepción, al rey, Manila, 8 de julio de 1739 (AGI, Filipinas, 227, ff. 1r-15r).

18 Memorial de Fray Francisco de la Encarnación, ORSA, al Rey, 1736, AGI, Filipinas, 227 , f. 2 r. 
nes sagradas, a las cuales cortaron cabezas, narices, orejas, arrojándolas al fuego, así como el robo de los ornamentos, reliquias y vasos sagrados ${ }^{19}$.

La declaración del ex provincial es interesante por dos motivos. Por un lado, ilustra las continuas ofensas de los «moros» a partir del saqueo de los templos e iglesias ${ }^{20}$; y por el otro, muestra la preocupación de los recoletos por el castigo a los culpables y el restablecimiento de la justicia ${ }^{21}$. Parecía evidente que los españoles no habían conseguido someter libre y voluntariamente a los mindanaos y joloanos, lo que era un requisito para justificar los derechos de Castilla al dominio temporal de las Filipinas, según lo dispuesto por el Sínodo de 1582, así como para la cobranza del tributo, so pena de restitución ${ }^{22}$.

El problema no era nuevo. Frente a los justos títulos que legitimaban la primera etapa de la conquista, el teólogo fray Francisco de Vitoria (Relictio de iuri belli, 18 de junio de 1539) consideraba que mientras que cualquiera podía emprender una «guerra defensiva» (iure defensionis), sólo los príncipes o gobernantes podían declarar la «guerra ofensiva» como respuesta a un previo acto injusto ${ }^{23}$. Al respecto, Vitoria consideraba que los fines de toda guerra eran la paz y seguridad del mundo cristiano ${ }^{24}$. A diferencia de Maquiavelo,

19 Idem. Dicho Memorial se incluye en la obra de Diego de Santa Teresa, 1743: 355. Igualmente, el alcalde mayor de la provincia de Calamianes, don Bernardo Jorge de Yllumbe, solicitó la ayuda de los gobernadores de Manila en sintonía con los padres recoletos (Carta del Provincial de los Agustinos Descalzos, fray Joseph de la Concepción, al rey, Manila, 8 de julio de 1739, AGI, Filipinas, 227, ff. 13r-14r). Al respecto, véase también Martínez Cuesta, 1995: 537.

20 En su Labor evangélica, el jesuita Diego de Oña (1701), narraba que antes de que el antiguo gobernador panameño y nuevo gobernador y presidente de la Audiencia de Manila don Sebastián Hurtado de Corcuera (1635-44) sometiera las islas de Mindanao y Joló, «raro era el años que estos [Mindanao, joloanos] no salieran a piratear, haciendo gravísimo daño, no sólo en las aldeas y casas, robando los ornamentos sagrados de que hacían escarnio y ultraje, sino llevando muchos cautivos indios, y estos en algunas ocasiones fueron en número tan crecido uno que cautivaron dos mil» (Oña, 1701: 48r-49r). Oña también refería los ataques de los camucones a los pueblos de Catbalogan y Paranas, en la isla de Samar (Bisayas), robando y matando a los indios enfermos, profanando las imágenes de las iglesias, y llevándose los cálices, alhajas y demás ornamentos sagrados (Oña, 1701: 261-262r).

${ }^{21}$ En palabras del mismo fray Francisco de la Encarnación, «de estas atrocidades no se ha tomado satisfacción alguna» (Memorial de Fray Francisco de la Encarnación, ORSA, al Rey, 1736, AGI, Filipinas, 227, f. 3r).

22 Sínodo de Manila..., 1988: 115-116. Gutiérrez, 1992: 81-86. Hidalgo Nuchera, 1993: 40-43.

23 Vitoria, 1917: 92. En cambio, el jesuita Francisco Suárez consideraba que «la guerra defensiva por ninguna ley está prohibida a los clérigos; ni la guerra agresiva por derecho natural» (Suárez, SJ, 1994, Sección Tercera), reproducido en Pereña, 1954, vol. II: 127).

${ }^{24}$ Beuchot, 1992: 37-40. 
el conflicto bélico no era un fenómeno político dominado por el interés del Príncipe, sino que estaba al servicio de la justicia universal ${ }^{25}$.

Luchar por la justicia, como principio universal de la filosofía cristiana, debía ser el leit motiv del rey cristiano. La «guerra justa» sería sólo el instrumento para alcanzar un fin justo y honesto, que no sería otro que el restablecimiento de la justicia. En este sentido, las denuncias de los agustinos recoletos contra la esclavitud de los vasallos del rey constituían un motivo suficiente, no sólo porque eran cristianos, sino porque la disminución de tributarios afectaba la Hacienda Real26. Por este motivo, la única causa de la guerra, según el jesuita Francisco Suárez (1548-1617), sería la restauración de la justicia. Sólo la injuria contra la reputación o el honor de los súbditos y el soberano puede ser reparada por la guerra. En otras palabras, si el desorden moral prevalece no hay justicia y se daña el bien común ${ }^{27}$.

A resultas de ello, los españoles reaccionaron, emprendiendo una serie de campañas militares, que como señalaba el provincial de los agustinos recoletos, fray Joseph de la Concepción, obedecía más a las quejas de los alcaldes mayores y a las repetidas instancias de los ministros doctrineros de las islas que al celo y afecto de los gobernadores a aquella provincia de Calamianes ${ }^{28}$. Nos encontramos inmersos en lo que Cesar A. Majul definió como la quinta etapa de las «Moro Wars», esto es, una guerra santa islámica en forma de continuas guerras y asaltos contra el poder imperialista católico de Filipinas ${ }^{29}$. Las fuentes españolas de la época, como la Disertación histórico-política del misionero franciscano fray Joseph Torrubia (1698-1761), OFM, presentaron aquellas expediciones de castigo contra las razias de los «piratas» malayo-mahometanos de Mindanao en clave heroica ${ }^{30}$. Frente a las tesis del padre Lucio Gutiérrez, para quien los misioneros españoles fueron víctimas de la

25 Pereña, 1954, vol. I: 133.

26 Memorial de Fray Francisco de la Encarnación, ORSA, al Rey, 1736, AGI, Filipinas, 227, ff. $12 \mathrm{r}-13 \mathrm{v}$.

27 Vitoria, 1917: 101. Suárez, 1954, Sección Cuarta, reproducido en Pereña, 1954, vol. I: 107.

28 Carta del Provincial de los Agustinos Descalzos, fray Joseph de la Concepción, al rey, Manila, 8 de julio de 1739, AGI, Filipinas, 227, ff. 10r-11r.

29 Majul, 1999: 233-297.

30 Como señala Manel Ollé, «la utilización de la etiqueta de pirata en las fuentes históricas está cargada de confusión conceptual, subjetividad patriótica y voluntad estratégica de deslegitimación de competidores y enemigos» (Ollé, 2014: 55). En este sentido, el fenómeno de la piratería malayo-mahometana, debería interpretarse más bien como el fracaso de las relaciones comerciales institucionalizadas $-\mathrm{y}$, por tanto, legales - entre poderes regionales en conflicto (Ollé, 2014: 56-57). Véase también Amirell y Müller, 2014: 1-23. 
«piratería mora», lo cierto es que la responsabilidad de las acciones «piráticas» fue siempre compartida ${ }^{31}$.

Los ataques coordinados de los «moros» para capturar esclavos no eran exclusivos de las poblaciones del sur, sino que fueron más bien una respuesta a los ataques previos de los españoles, ávidos de adquirir esclavos mediante la «guerra justa» ${ }^{32}$. No olvidemos que el rey Felipe II (1556-98), siguiendo los planteamientos jurídico-teológicos vitorianos, se consideraba legitimado a ejercer su dominio temporal sobre las Filipinas por el derecho natural de predicar el evangelio. Y si los infieles cometían alguna injusticia contra inocentes o se resistían a la predicación pacífica se justificaba la «guerra justa» ${ }^{33}$.

Tras los infructuosos ataques al presidio de Zamboanga (enero-abril, 1721), el sultán de Joló Badar ud-Din propuso un nuevo acuerdo de paz (1726) ${ }^{34}$. El gobernador de las Filipinas, don Fernando Valdés Tamón (1729-39), accedió, y cuando estaban a punto de firmar el tratado, un año después los «moros» atacaron a los cristianos en Cebú, en las costas de Mindoro y en ciertas regiones de Mindanao. Sin embargo, no fue hasta mayo de 1730, cuando una escuadra de 20 embarcaciones tripuladas por tres mil hombres bien pertrechados, al mando del rey de Tawitawi (apodado «Bigotillos»), hermano del sultán de Joló, atacó las islas del sur del archipiélago filipino. Primeramente, asolaron e hicieron cautivos en la pequeña isla de Dumaran, al norte de Palawan, atacando el histórico fortín de Santa Isabel de Taytay. Seguidamente quemaron la iglesia, el convento y el pueblo, retirándose al fortín que mantenían en Ipolote, al sur de Labo ${ }^{35}$. Como respuesta a los continuos ataques de los joloanos sobre la provincia de Calamianes, el gobernador Valdés Tamón, militar profesional de experiencia contrastada, así como los oidores de la Audiencia de Manila, reconocieron la necesidad de mantener el presidio de Zamboanga, restituyendo la guarnición de 600 hombres que tuvo anteriormente y aumentando la flota a siete galeras, con sus pertrechos de guerra, municiones y víveres necesarios ${ }^{36}$.

31 Gutiérrez, 1992: 191. Oña, 1701: 234r, narra las acciones «piráticas» de los españoles no sólo contra los musulmanes, sino incluso contra «nuestros pueblos amigos».

32 Hidalgo Nuchera, 1995: 283; 1994: 64-65.

33 Cushner, 1971: 102. Hidalgo Nuchera, 1993: 24.

34 Barrio, 2012: 56-57.

35 Ibidem: 59-63. Según el relato de fray Francisco de la Encarnación, «[los musulmanes] cautivaron más de 500 personas, apresaron seis, u ocho embarcaciones (...), ultrajaron también las imágenes de los santos, pues sacándolas de sus nichos, y arrastrándolas por el suelo, les decían mil blasfemias», Memorial de Fray Francisco de la Encarnación, ORSA, al Rey, 1736, AGI, Filipinas, 227, f. 5r. Véase también Suárez Fernández, 1990: 544. Martínez Cuesta, 1995: 539.

36 Barrio, 2012: 69. 
A pesar de la escasez de recursos, el gobernador reconoció la necesidad de emprender acciones de castigo, «llevando la guerra a su propio territorio» ${ }^{37}$. Para ello el 6 de junio de 1730 reunió la Junta de Guerra en la que se decidió enviar ciento cincuenta hombres con pertrechos y víveres para socorrer a los defensores del fortín de Santa Isabel ${ }^{38}$. El 28 de junio dio cuenta al Consejo de Indias de la construcción de cuatro nuevas galeras guardacostas ${ }^{39}$ para la defensa de Calamianes, y dos más para patrullar la zona de Zamboanga, pero la demora en la llegada del galeón de Manila y del subsidio anual - el socorro o situado- previsto retrasó los planes del gobernador ${ }^{40}$. La Audiencia de Manila se opuso a sufragar los costes de manutención, así como a la construcción de otro fuerte en el puerto de la Caldera, al sur de Mindanao, con el consiguiente traslado de cien familias boholanas para su poblamiento ${ }^{41}$. Frente a la firme oposición de los oidores, el gobernador no tuvo más remedio que recurrir a la ayuda de los naturales de las Provincias, que contribuyeron con un donativo gracioso de 12.000 pesos, algunas armas y esclavos ${ }^{42}$.

Para contrarrestar los ataques joloanos, el gobernador Valdés Tamón organizó una expedición punitiva, liderada por el general guipuzcoano don Ignacio de Iriberri, que como bien señala Barrio Muñoz, se revistió «con tintes de cruzada ${ }^{43}$. El grueso de la flota salió de Manila el 4 de marzo de 1731 y estaba compuesta de las cuatro galeras construidas en junio de 1730 comandadas por el propio general Iriberri, el almirante don Manuel del Rosal, y los capitanes don Pedro Zacarías Villarreal y don Andrés de Palacio, respectiva-

37 Ibidem: 70-71.

38 Ibidem: 61.

39 Las galeras eran embarcaciones ideales para asaltos anfibios. Se utilizaban fundamentalmente para interceptar barcos enemigos. La mayor parte de los remeros eran esclavos condenados a trabajos forzosos, por lo que su lealtad era escasa (Barrio, 2012: 71). En Filipinas fueron muy utilizadas para proteger las costas de «piratas» malayo-musulmanes. Al respecto, véase Rodríguez Castillo, 2017: 153-166.

40 Memorial de Fray Francisco de la Encarnación, ORSA, al Rey, 1736, AGI, Filipinas, 227, ff. $13 \mathrm{v}-14 \mathrm{r}$.

41 Barrio, 2012: 67. En respuesta al despacho del rey, con fecha el 29 de marzo de 1725, la Audiencia de Manila dictaminó que, dado el aumento de cuatro galeras a seis, la defensa de las islas quedaba asegurada de cualquier hostilidad y, por lo tanto, no era necesaria la construcción de otro fuerte en el puerto de la Caldera (el primero se había construido en 1597), así como el envío de cien familias boholanas para su poblamiento, habida cuenta de la escasez de recursos de las Cajas Reales de México (Carta de la Audiencia de Manila al rey, Manila, 9 de julio del 1731, AGI, Filipinas, 227).

42 Barrio, 2012: 71.

43 Idem. 
mente, así como de diversas fragatas, paquebotes o champanes, y caracoas ${ }^{44}$ que se fueron incorporando tras la llegada a los presidios de Yloylo y Zamboanga ${ }^{45}$. Primeramente, arrasaron la isla de Talobo, a una legua de Joló, destruyendo el pueblo y las salinas. A continuación, llegaron hasta la fortaleza de Bual, dando muerte al dato local. Finalmente arribaron a la isla de Capual, donde hicieron lo propio, saqueando sembrados y salinas. Finalmente, el 23 de abril de 1731 se produjo el desembarco en el puerto de Joló, pero los españoles no pudieron mantener la posición debido al escaso número de soldados. Por este motivo decidieron retirarse al presidio de Zamboanga desde donde realizaron nuevas expediciones de castigo contra los joloanos, regresando a Manila en junio de $1731^{46}$.

En noviembre de 1731 otra expedición zarpó de Zamboanga al mando del capitán don Pedro Zacarías y Villarreal, nombrado gobernador y castellano del presidio en $1739^{47}$. Su objetivo era socorrer al sultán de Maguindanao (o Tamontaca $)^{48}$ de los ataques de su sobrino, el príncipe Malinog (i-1748), hijo de Bayan ul-Anwār, que se había sublevado con el apoyo de los datos de treinta pueblos del río Grande contra su tío, Muhammad Jafar Sadiq Manamir (Maulana Diafar Sadicsa Manamir en las fuentes españolas), aliado de los españoles, proclamándose sultán de Salangan ${ }^{49}$. A su llegada a Maguindanao la flota española, compuesta de dos galeras, dos paquebotes o champanes, se unió a la armada del sultán, integrada por «once embarcaciones grandes, y treinta medianas, que comandaban dos príncipes suyos, con mucha gente y armas». Arribaron hasta las puertas de la corte de Malinog, «población muy grande, defendida por seis fortalezas, en las que había treinta cañones de a doce, ocho, y seis», pero no consiguieron matarlo. A pesar de las defensas enemigas los españoles salieron victoriosos, causando numerosas bajas al enemigo y arrasando pueblos y sementeras a su paso ${ }^{50}$. De vuelta a Zamboan-

44 Las fragatas y pataches eran navíos de vela más pequeños que los galeones. Las caracoas eran embarcaciones ligeras, con portaremos exteriores y sin cubierta, cuyo pequeño calado les permitía navegar por estrechos arrecifes inaccesibles para las lentas y pesadas galeras o galeotas de estilo mediterráneo (Rodríguez Castillo, 2017: 153-156).

45 Torrubia, 1736: 49-50. Barrio, 2012: 72.

46 Torrubia, 1736: 49-51. VV.AA., 1989: 544. Barrio, 2012: 72-73.

47 Rodríguez García, 1976: 58-59.

48 En la isla de Mindanao, la zona de mayor presencia islámica correspondía a Magindanao (actual Maguindanao), a lo largo de los márgenes del río Pulangi, que los españoles denominaban Rio Grande de Mindanao (Saleeby, 1973: 13).

49 Donoso, 2012: 199-204. Barrio, 2012: 57, 99.

50 Torrubia, 1736: 53. 
ga, la flota del capitán Zacarías atacó la vecina isla de Basilán ${ }^{51}$, provocando grandes pérdidas y regresando luego a Manila en junio de $1732^{52}$.

\section{El PRESidio De Zamboanga a DEBATE}

Los trabajos de James F. Warren sobre lo que definió como la «zona Sulú» explican la expansión de los sultanatos de Mindanao y Joló en base al corsarismo y el tráfico de esclavos. A consecuencia de la expansión de la economíamundo capitalista, a partir de 1768 los sultanatos del sudeste asiático desarrollaron una economía de base esclavista sostenida que favoreció el auge de la «piratería» ${ }^{53}$. Sin embargo, a principios del siglo XVIII, los esclavos capturados por los corsarios malayo-musulmanes respondían más bien al reflejo del estatus y la jerarquía de sus poseedores que al engranaje de una economía del capitalismo global.

En enero de 1733 los joloanos asaltaron el pueblo de Calatán, en la provincia de Calamianes, quemando la iglesia, el convento y cautivando a muchos cristianos ${ }^{54}$. El 14 de marzo de 1733 se firmó un tratado en Maguindanao (o Tamontaca) entre el sultán Maulana Diafar, por un lado, y el general Juan Antonio Jove Bernardo, comandante en jefe de la flota que operaba en Mindanao, que obligaba a acudir al auxilio de una de las partes ante un enemigo común. No sólo se garantizaba así la libertad comercial sino la liberación de todos los cautivos cristianos súbditos del rey Felipe $\mathrm{V}$ que estuviesen en su poder ${ }^{55}$.

En resumen, quedaba claro que los continuos asaltos de los musulmanes que pertenecían al sultanato joloano - Joló, Tawitawi y norte de Borneo- en busca de esclavos perjudicaban la libertad de comercio, así como la expansión del cristianismo en las islas de Mindoro y Calamianes. Para los vicarios provinciales de los recoletos, la mayoría de expediciones despachadas desde 1734 hasta 1738 a las costas de Paragua no había dado ningún fruto, revelando tensiones internas entre los capitanes (don Andrés de Palacios, don Juan Jo-

51 La isla de Basilán era «el granero de Joló y Mindanao» y fue evangelizada por el padre Pedro Gutiérrez (Oña, 1701: 1276r). Véase también Barrio, 2012: 72-73.

52 Torrubia, 1736: 87-90.

53 Warren, 1981; 2000; 2002.

${ }_{54}$ Memorial de Fray Francisco de la Encarnación, ORSA, al Rey, 1736, AGI, Filipinas, 227, f. $5 \mathrm{v}$.

55 Barrio, 2012: 104-105, 112-117. 
seph de Coronado y Vázquez) que las integraban ${ }^{56}$. Asimismo denunciaban «el poco calor que por acá se ha puesto para la seguridad, y defensa de dicha provincia [de Calamianes], ni para proporcionar los medios conducentes a cerrar el paso a la Morisma, y evitar tantas y tan sacrílegas hostilidades $\rangle^{57}$. La solución, pues, no era otra que abandonar definitivamente el presidio de Zamboanga, debido a su elevado coste de mantenimiento y escasa eficacia. En su lugar, se proponía (re)conquistar la isla de Paragua e islas adyacentes hasta Balabac, cuyos habitantes, a diferencia de los mindanaos, eran potenciales cristianos, con el fin de instalar un nuevo presidio, o fuerza de piedra en la ensenada de Tagusao, así como tres «presidios o fuerzas pequeñas» en la isla de Balabac, en el puerto de Labo y en el de Babuyan, que apoyadas por una armada de cuatro galeras o piraguas, fueran capaces de atajar los ataques de los $\langle\text { moros }\rangle^{58}$.

Mientras los agustinos recoletos trataban de defender sus posiciones en la provincia de Calamianes, los jesuitas consideraban que el proceso de conquista y evangelización de las Filipinas no sólo no había concluido, sino que debía extenderse hacia el extremo sur de las Filipinas. En 1728, el padre Pedro José de Sisa, SJ, rector del colegio de Zamboanga, lamentaba contar con tan solo dos padres para atender a 2.299 almas en los alrededores del presidio, entre bautizados y catecúmenos, por lo que solicitaba que se aumentase el número de religiosos destinados en la región ${ }^{59}$. Para cumplir este objetivo destacados miembros de la orden ignaciana en Manila aconsejaron el abandono la pequeña y escasa misión de las Marianas en beneficio de los más abundantes y numerosos habitantes de la gran isla de Mindanao, donde ilustres mártires, como el padre Juan de Carpio (1583-1634), habían encontrado la muerte ${ }^{60}$.

No hay que olvidar que desde 1633 los shogunes habían impuesto el sakoku, o «cierre del país» a los extranjeros, en especial a los católicos provenientes de Portugal y España, lo que propició el aislamiento del Japón ${ }^{61}$.

56 Carta del Provincial de los Agustinos Descalzos, fray Joseph de la Concepción, al rey, Manila, 8 de julio de 1739, AGI, Filipinas, 227, ff. 7r-8r.

57 Ibidem, f. 10r.

58 Ibidem, ff. 11r-12r. Véase también el escrito de Fray Benito de San Pablo, ORSA, «Testimonio de los autos y diligencias sobre que la fuerza de Santa Ysabel... se mude de sitio y parage, Convento de San Sebastián, Manila, 8 de mayo de 1733, AGI, Filipinas, 705. Citado en Barrio, 2012: 77, 80.

59 Barrio, 2012: 120-121.

60 Coello de la Rosa, 2016: 153, 268. Sobre la «feliz muerte» del padre Carpio, véase también Oña, 1701: 832-839r.

61 Boxer, 1967: 352. 
A resultas de la política anti-cristiana del gobierno de Tokugawa Iemitsu (1623-51), los jesuitas vieron truncados sus deseos de evangelizar las tierras niponas y buscaron otros espacios de conquista espiritual al sur de Filipinas ${ }^{62}$. La difusión que tuvieron las tres cartas - las «Inocencianas» de 1645, 1648 y 1649- que el obispo de Puebla de los Ángeles, Juan de Palafox y Mendoza (1640-53), dirigió al papa Inocencio X (1644-55) suscitaron gran inquietud en amplios sectores eclesiásticos, especialmente dominicos y jansenistas, cuyas críticas al relajamiento moral de los jesuitas, ejemplificadas en la doctrina del probabilismo, dieron dado lugar a una serie de enconados debates y enfrentamientos que llegaron a pedir la supresión de la Compañía de Jesús ${ }^{63}$.

Para evitarlo, los provinciales de la orden trataron de demostrar su compromiso con la evangelización de los «moros» del sur de Filipinas, a pesar de la oposición del gobernador Valdés Tamón, quien, como señaló José Ángel del Barrio en su tesis doctoral, no compartía en absoluto los deseos de la Compañía de aumentar la presencia española en Mindanao ${ }^{64}$. Desconocemos si el objetivo final de los jesuitas era evangelizar el «Maluco Grande», como la llamaban los moluqueños. De lo que estamos seguros es de que el gobernador nunca pretendió colonizarla ni tampoco establecer bases militares o presidios en la región, sino más bien (re)establecer una armada fija en las Bisayas («La Armada de Pintados»), apoyada en poblaciones ya existentes. Asimismo consideraba que debía concentrarse a los naturales en núcleos más densamente poblados y exigir que la población local participara activamente en la defensa de sus costas, permitiéndoles la captura de botín y esclavos ${ }^{65}$.

Y así fue. En 1734, el gobernador Valdés Tamón tuvo que enfrentar a la vez dos focos en conflicto: por un lado, frenar los continuos asaltos de los joloanos a la provincia de Calamianes, lo que obligó a la Junta de Guerra, reunida en Manila el 11 de agosto de 1733, a enviar dos galeras pequeñas a la isla de Palawan, aumentando la guarnición de Taytay en veinticinco hombres, y estudiando la construcción de un nuevo fuerte de piedra en el municipio de Tagusao. Esta medida situaba al gobernador en la órbita de los agustinos recoletos, cuyo provincial, como vimos, recomendaba el estableci-

62 Se da la circunstancia de que uno de ellos, el padre napolitano Marcelo Francisco Mastrilli (1603-1637), a quien el padre Diego de Oña, SJ, llamó el «Moisés jesuita», murió martirizado el 17 de octubre de 1637 en el monte Unzen, en Nagasaki, después de servir como misionero en Mindanao durante el gobierno de don Sebastián Hurtado de Corcuera (Oña, 1701: 997r, 1080r).

63 Burrieza Sánchez, 2004: 189-192.

64 Barrio, 2012: 66-69.

65 Ibidem: 69-70, 86. 
miento de un presidio en Palawan. Por el otro, evaluar las guerras intestinas del reino musulmán de Mindanao, lo que obligó al gobernador a intervenir. Tras la nueva Junta de Guerra, convocada en Manila el 5 de septiembre de 1733, se envió una armada de cuatro galeras (Nuestra Señora del Rosario, San Felipe, San Carlos y San Fernando) al mando del sargento mayor don Francisco de Cárdenas Pacheco ${ }^{66}$. La armada, integrada por 2.750 hombres, en su mayoría nativos de las Bisayas, salió de Manila el 30 de diciembre y recorrió las costas de Mindanao para intimidar a los «moros» joloanos, llegando hasta la isla de Basilan, donde los «piratas» malayo-mahometanos tenían sus bases principales ${ }^{67}$.

A diferencia del parecer de los jesuitas, el gobernador Valdés Tamón consideraba que nunca debió restablecerse el presidio de Zamboanga, en especial por lo costoso de su mantenimiento, pero que una vez hecho, había que conservarlo, sosteniendo una guarnición de 600 hombres y una pequeña armada de seis galeras para defenderlo ${ }^{68}$. Este era el único medio, según su parecer, para contener el avance de los joloanos, aunque dicha medida nunca se llegó a aplicar ${ }^{69}$. Asimismo rechazó la opinión de los jesuitas de construir un fuerte cercano al puerto de la Caldera, si bien acabó aceptando el traslado de cien familias de boholanos para poblarlo ${ }^{70}$. Si en 1725 el provincial de la orden ignaciana consideraba que el fuerte era fundamental para la defensa del presidio de Zamboanga, y por ende, de Manila ${ }^{71}$, los oidores de la Audiencia de Manila se opusieron por «haber faltado los cinco mil pesos que estaban aplicados para ese efecto» ${ }^{72}$.

66 Poco tiempo después, el sargento mayor Cárdenas fue designado oficialmente como gobernador del presidio de las islas Marianas (1734-40), Traslado auténtico del real título de gobernador de las islas Marianas conferidas al general don Francisco de Cárdenas Pacheco (1735), AGI, Filipinas, 543, ff. 1r-28v.

${ }^{67}$ Relación de servicios de don Francisco de Cárdenas Pacheco, Gobernador y Capitán General de las islas Marianas, AGI, Indiferente, 146, n. ${ }^{\circ}$ 99, ff. 1r-4r.

68 Barrio, 2012: 66-69.

69 VV.AA., 1989: 209.

70 Barrio, 2012: 69.

71 VV.AA., 1989: 169, 191.

72 Informe de la Audiencia de Manila al Rey, con fecha en Manila, 9 de julio de 1731, AGI, Filipinas, 227. 
IMAGen 1. MAPA DE LAS FiLIPINAS (1752), DE JACQUES-NicOlaS BELLIN (1703-1772)

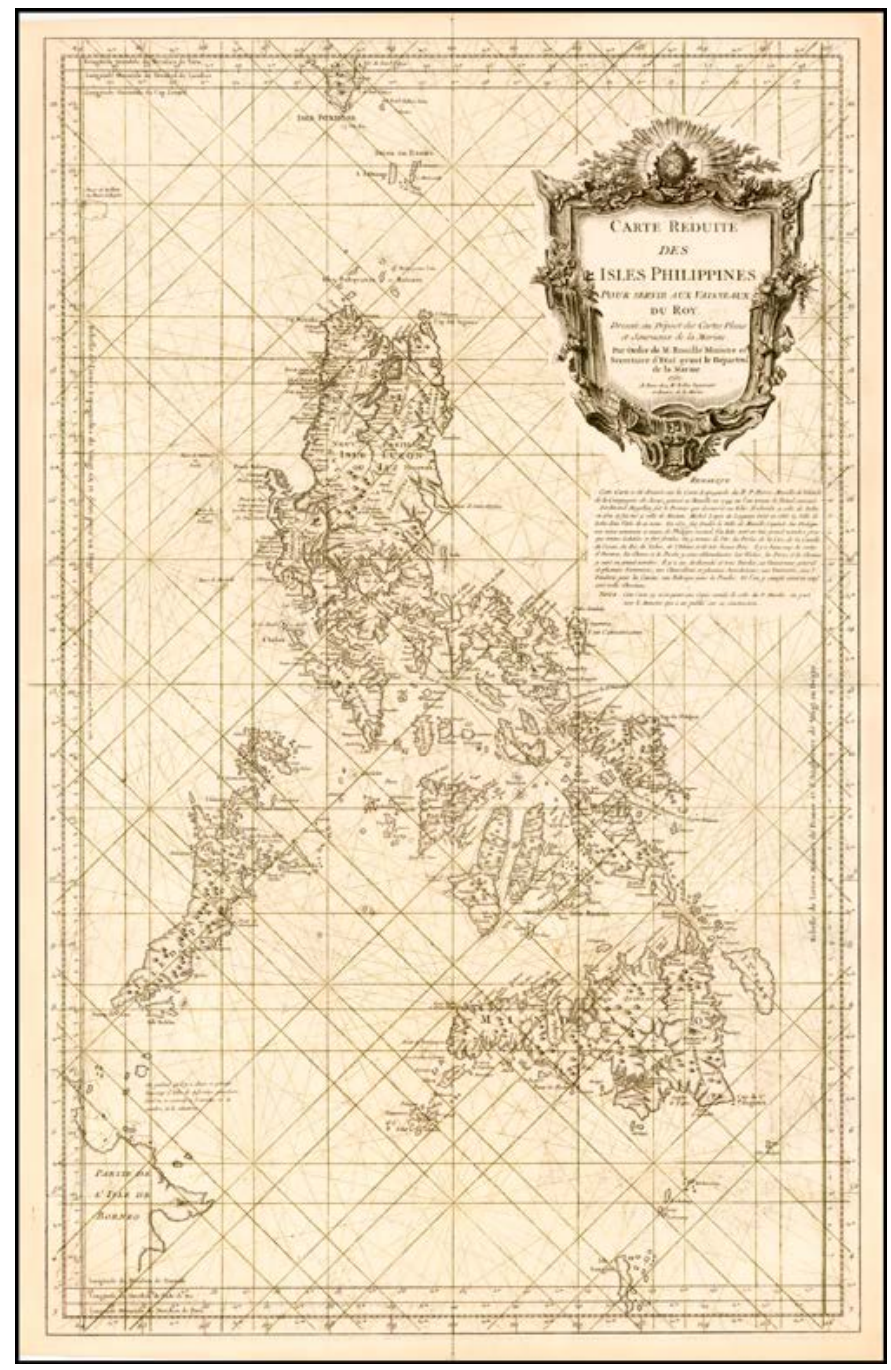

En julio de 1734, los «moros» joloanos asaltaron nuevamente el presidio de Taytay, llegando hasta el partido de Calabite, en la isla de Mindoro, quemando pueblos y cautivando cristianos ${ }^{73}$. A causa de la cercanía a Manila, el

73 Memorial de Fray Francisco de la Encarnación, ORSA, al Rey, 1736, AGI, Filipinas, 227, f. 6r. Véase también Martínez Cuesta, 1995: 539-540. 
18 de diciembre de 1734 la Junta de Guerra dispuso un nuevo plan defensivo basado en «aglutinar pueblos, fortificarlos y crear una flotilla ligera de unas 15 o 20 caracoas (costeada por la Real Hacienda y con un pequeño impuesto sobre los naturales que se hubiesen de beneficiar de la misma) que actuaría desde las Bisayas, en contacto con las galeras y fragatas más grandes sitas en Zamboanga, Cavite o Taytay» ${ }^{74}$.

Sin embargo, no todos los religiosos estaban de acuerdo en mantener el presidio de Zamboanga. Según el citado Memorial del fraile Francisco de la Encarnación, OAR, la causa de tales desgracias debía atribuirse exclusivamente al restablecimiento de dicho presidio, pues consideraba que no desembarazaba ni impedía el paso de los «moros» hasta las provincias de Calamianes y Mindoro, situadas a las puertas de Manila ${ }^{75}$. Mientras que su erección se atribuía a la necesidad de socorrer el presidio de Ternate, una vez que fue abandonado por las fuerzas españolas y que su presencia en Molucas había disminuido, el presidio de Zamboanga carecía de utilidad ${ }^{76}$. Por consiguiente, tras más de cuarenta años de paz, el fraile recoleto concluía que «con dicho restablecimiento se ha despertado al dormido», provocando «gravísimos perjuicios espirituales, y temporales de aquella Christiandad, y menoscabos crecidísimos de la Real Hacienda de Vuestra Majestad, así con los muchos tributos que han faltado de tantos cautivos, y muertos de los mahometanos». Además, si como aseguraba, todos los habitantes y descendientes de Zamboanga eran irreductibles mahometanos, "¿qué adelantamiento de la Christiandad se puede prometer?, ¿qué acrecentamiento de la Real Hacienda de Vuestra Majestad?» ${ }^{77}$.

A pesar de estos inconvenientes, el gobernador se vio obligado a ceder a favor de los jesuitas. El 15 de octubre de 1735, el jesuita Pedro Murillo Velarde y Bravo (1696-1753), designado visitador de las misiones costeras de Zamboanga y Dapitán, había recomendado al provincial de la orden su conservación ${ }^{78}$. El gobernador llevó el asunto a la Junta de Hacienda, y como

74 Barrio, 2012: 86-89.

75 Memorial de Fray Francisco de la Encarnación, ORSA, al Rey, 1736, AGI, Filipinas, 227, f. 8 v.

76 Ibidem, f. 9v.

77 Memorial de Fray Francisco de la Encarnación, ORSA, al Rey, 1736, AGI, Filipinas, 227, ff. $7 \mathrm{v}-8 \mathrm{r}$.

78 Archivum Romanum Societatis Iesu (en adelante, ARSI), Philipp, vol. 3, f. 200r. Próximamente aparecerá la edición de este manuscrito, a cargo de Alexandre Coello de la Rosa y Verónica Peña Filiu, bajo el título, Labor Evangélica. Ministerios apostólicos de los obreros de la Compañia de Jesús, (ca. 1701), del Padre Diego de Oña, SJ (1621-1755), Madrid, Sílex, 2019. 
señala Barrio Muñoz, ordenó al alcalde mayor de Cebú el traslado de nativos boholanos a Zamboanga, quedando exentos de tributos, polos y demás servicios personales por espacio de cuatro años ${ }^{79}$. Ese mismo año, el rey Felipe V aprobaba las medidas del gobernador, confirmando así la voluntad de la Compañía de Jesús de permanecer (y aumentar) la grey cristiana en el sur de Filipinas ${ }^{80}$.

Desde su llegada al trono de Joló en 1735, el sultán Mohammed Azim Ud-Din I (más conocido como Alimudín, 1735-48, y 1764-74) expresó su deseo de enviar una embajada para negociar la paz con los españoles. En 1736, los príncipes de Mindanao escribieron al gobernador Valdés Tamón, mostrándole su voluntad de firmar un acuerdo de paz ${ }^{81}$. El 18 de enero de 1737 llegaron a Manila y poco después, el 1 de febrero, los joloanos juraron un tratado de paz de carácter perpetuo por el que se comprometían a devolver los cautivos de guerra, a respetar la libertad de comercio y a auxiliarse mutuamente en caso de conflicto ${ }^{82}$.

Sin embargo, las hostilidades, lejos de cesar, aumentaron ${ }^{83}$. Según Wenceslao E. Retana (1862-1924), las armadas que se habían despachado desde Manila al sur costaban $\left\langle\right.$ ríos de sangre y plata» ${ }^{84}$. Como agudamente señalaba fray Francisco de la Encarnación, «aunque se han ponderado los buenos efectos de dichas Armadas, no se ha dicho, ni puede decirse con verdad, que se haya rescatado un Christiano siquiera» ${ }^{85}$.

\section{El reformismo ilustrado del procurador Juan Joseph Calvo, SJ}

A partir de 1737 los gobernadores de Manila se esforzaron por contener los levantamientos indígenas, especialmente tras la muerte del sultán de Ma-

79 Barrio, 2012: 121.

80 Ibidem: 114.

81 Ibidem: 131-132.

82 Ibidem: 133-134.

83 Cruikshank, 1979: 141-185. García-Abásolo, 2012: 226.

84 Retana, 1897: xxii. De acuerdo con fray Francisco de la Encarnación, los gastos anuales del presidio de Zamboanga ascendían a más de 21.500 pesos, sin ser suficientes «para poder contener al Joló, y mucho menos al Borney, y a otros Moros», Memorial de Fray Francisco de la Encarnación, ORSA, al Rey, 1736, AGI, Filipinas, 227, f. 9v.

85 Ibidem: f. 9v. Se refería sobre todo a la Armada de Pintados, una flota permanente cuyos barcos, de características similares a los «moros» - ahora llamados tirones - eran construidos y tripulados por los habitantes de las islas que sufrían los saqueos, dependiendo de las autoridades malinenses la provisión de los efectos bélicos necesarios (García-Abásolo, 2012: 226). 
guindanao a manos del príncipe Malinog, enemigo mortal de los españoles, así como los ataques de navíos ingleses y holandeses, impidiendo posibles alianzas entre ellos que pusieran en peligro la soberanía española en las Filipinas $^{86}$. Sin embargo, la crisis económica obligaba a replantearse la necesidad de seguir manteniendo algunos presidios, como el de las islas Marianas, especialmente después de que las guerras chamorras de finales del siglo XVII hubieran diezmado a la población.

Imagen 2. MaPa DE LAS ISLAS MARIANAS (1700), De Alonso LóPez, 1672

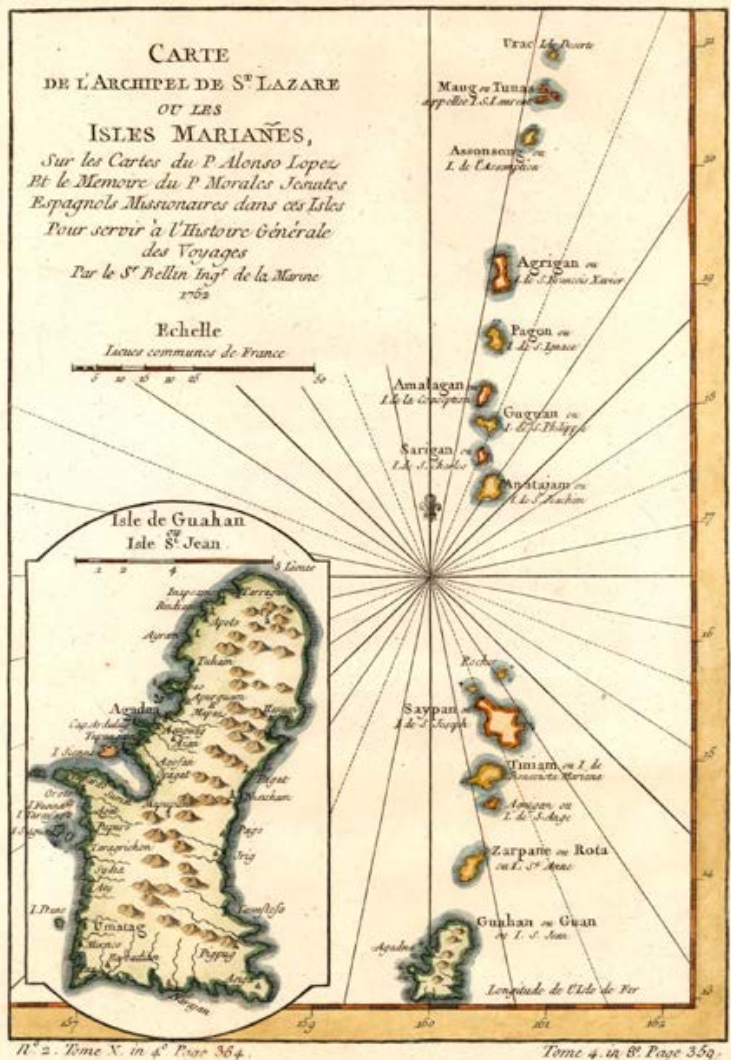

El 20 de junio de 1737, cuando todavía gobernaba Valdés Tamón, se hizo una Junta con los oidores y oficiales reales de la Audiencia, así como con dos

86 Donoso, 2012: 203. Luengo, 2017: 741. 
jesuitas que habían sido misioneros en las islas Marianas. Decían que a consecuencia de las epidemias y las guerras los nativos habían disminuido considerablemente, y con ellos, la mano de obra que les podría permitir obtener algún género de riqueza o beneficio. De los miles de indios que hallaron los jesuitas a su llegada en 1668, apenas se contabilizaban 2.600 repartidos entre las islas de Guam y Rota ${ }^{87}$. Por esta razón la Junta acordó que era indispensable reducir el destacamento de 130 soldados que había en 1736 a 25 o 30 al mando de un cabo o sargento mayor con 600 pesos de sueldo, con lo cual se obtendrían muchos beneficios ${ }^{88}$. En primer lugar, la Real Hacienda podría ahorrarse 11.000 pesos anuales en concepto de sueldos que podrían destinarse a otros presidios de mayor necesidad, como el de Zamboanga, donde debían residir alrededor de cincuenta padres jesuitas, que a juicio del procurador, serían destinados próximamente a las nuevas misiones en los sultanatos de Joló y Maguindanao ${ }^{89}$. En segundo lugar, con dicha reducción la Corona evitaría los gravámenes que los gobernadores, oficiales y soldados infringían a sus moradores.

A pesar de los acuerdos de paz, los «piratas» malayo-musulmanes siguieron hostigando las posiciones españolas en Mindoro y Calamianes. Algunos historiadores, como Vicente Rodríguez, basándose en las cartas del brigadier Gaspar de la Torre (1739-45) al rey Felipe V, sostuvieron que se trataba de «correrías de piratas» sin mayor importancia ${ }^{90}$. Sin embargo, otras fuentes, como la carta que el provincial de los agustinos recoletos, fray Juan de San Antonio, escribió al rey, con fecha en Manila, 8 de julio de 1740, describía

87 Catalogus Christianorum quos colit societas in Philippinis. Anno 1737, ARSI, vol. 14, Supplementum ad Historiam, 1584-1750, ff. 110r, 117r. El dato viene confirmado por otro jesuita, el misionero Joseph Bonani, cuya carta de fecha en Agaña, 1 de enero de 1740, describía la alarmante disminución demográfica de las islas Marianas a una persona anónima de Viena (AHCJC, FILCAR. E.I, a-18, Cartas de misioneros, 1677-1750, f. 251).

88 AHCJC, FILPAS-092, 1745-46, f. 50r.

89 Es de sobras conocido que Joseph Calvo, procurador de la Compañía de Jesús, había defendido la necesidad de establecerse en esa nueva «frontera de la cristiandad» que constituían los reinos de Zamboanga y Joló, Real Academia de la Historia, Madrid (RAH), Fondos Cortes, 567, 9-2674. Josep Calvo, Información sobre el presidio de Zamboanga, Biblioteca Nacional, Madrid, Sala Cervantes, Libros Filipinos de don Antonio Griaño, R/33375/7. A diferencia de los cien pesos y cien fanegas de arroz que se acostumbraba a dar a los misioneros de las Filipinas, los misioneros destinados a Joló y Tamontaca obtendrían, según el padre Calvo, doscientos pesos de limosna, AHCJC, FILPAS-092, 1745-46, f. 54v. Véase también Lévesque, 1999: 590. Asimismo, recomendaba subir el salario del gobernador de Zamboanga a 1.000 pesos, de manera que no tuviera que valerse «de otros arbitrios», AHCJC, FILPAS-092, 1745-46, f. 52r. Véase también Lévesque, 1999: 590.

90 Rodríguez García, 1976: 198. 
los crueles asaltos efectuados por una armada «mora» compuesta de dieciséis o dieciocho caracoas, que en octubre de 1739 asoló los pueblos de Bulalacao, Mangaring y Ylilim (o Ililim), en la isla de Mindoro, capturando a ciento cincuenta personas como esclavas ${ }^{91}$.

Asimismo, uno de sus cofrades, el padre fray León de San Joseph, natural de Extremadura, fue cruelmente martirizado en el pueblo de Ylilim, «cortándole primero sus manos consagradas, y después la cabeza con otras mucha crueldades, que acostumbra su impiedad a hacer con los cuerpos de los ministros evangélicos» ${ }^{92}$. No sólo los jesuitas, sino también los «esforzados recoletos», como los definía su Provincial, cumplieron sus «deseos del martirio» en remotas islas para la defensa de la cristiandad ${ }^{93}$. Otro recoleto, fray Hipólito de San Agustín, natural de Ávila, que había sido enviado a Mindanao para fundar una misión, fue capturado el 20 de mayo de 1740 por tres embarcaciones de «moros» cerca de la punta de Pola, en la isla de Mindoro, permaneciendo prisionero en la nave capitana en hábito blanco y con un dogal al cuello hasta que murió en $1746^{94}$.

Ante esta cruda realidad, el provincial lamentaba la falta de determinación del flamenco Gaspar de la Torre, quien el 7 de septiembre de 1739 tomaba posesión del cargo de gobernador ${ }^{95}$. Lo acusaba de haber hecho «bien poco aprecio, haciendo poca merced a los religiosos, y dudando de la veracidad de su informe con palabras, y expresiones muy ajenas del debido respeto a lo sagrado, y nada propias de católicos pechos $\gg{ }^{96}$. Y sobre todo, de organizar a principios de 1740 una armada de castigo de tres galeras pequeñas y mal pertrechadas y un champán con escasos efectivos contra los «moros», cuyo objetivo nunca fue «tomar satisfacción de tantos daños» y rescatar a los cautivos, sino espantarlos ${ }^{97}$. En su defensa, el gobernador aducía falta de medios

91 Carta de fray Juan de San Antonio, ORSA, al rey, Manila, 8 de julio de 1740, AGI, Filipinas, 227, f. 2r. Véase también Martínez Cuesta, 1995: 540.

${ }_{92}$ Carta de fray Juan de San Antonio, ORSA, al rey, Manila, 8 de julio de 1740, AGI, Filipinas, 227, f. 4r. Véase también Martínez Cuesta, 1995: 537.

93 Carta de fray Juan de San Antonio, ORSA, al rey, Manila, 8 de julio de 1740, AGI, Filipinas, 227, f. 6r. Véase también Martínez Cuesta, 1995: 535-547.

94 Carta de fray Juan de San Antonio, ORSA, al rey, Manila, 8 de julio de 1740, AGI, Filipinas, 227, f. 12r. Véase también Martínez Cuesta, 1995: 538, 599. Rodríguez García, 1976: 198.

95 Rodríguez García, 1976: 42.

96 Carta de fray Juan de San Antonio, ORSA, al rey, Manila, 8 de julio de 1740, AGI, Filipinas, 227, f. 4r.

97 Carta de fray Juan de San Antonio, ORSA, al rey, Manila, 8 de julio de 1740, AGI, Filipinas, 227, f. 13r. Carta del gobernador De la Torre al rey Felipe V, con fecha en Manila, 30 de junio de 1740, AGI, Filipinas, 440, citada en Rodríguez García, 1976: 209. Sobre el 
y caudales en las Cajas Reales, añadiendo que «por más órdenes que de esa Real Corte vengan para poner freno a la Morisma, no remitiendo plata de México para el efecto, nunca se podrán poner en ejecución ${ }^{98}{ }^{98}$.

Por su parte, los superiores jesuitas en Manila permanecían atentos a la posibilidad de participar en la fundación de un protectorado español en el reino de Maguindanao (o Tamontaca) ${ }^{99}$. Sus intereses consistían en mantener el presidio de Zamboanga como punta de lanza de una presumible penetración en la isla «mora». En este sentido, el sultán de Magindanao se convirtió en un aliado indispensable para contener el avance del «pérfido» Malinog, cuya férrea oposición a los españoles dificultaba la penetración del cristianismo en la región ${ }^{100}$.

Ante la necesidad de asegurar las Bisayas y protegerlas de los ataques de los mindanaos y joloanos, las misiones religiosas (principalmente, las de los jesuitas y agustinos recoletos) actuaban como elementos indispensables de estabilización fronteriza, convirtiéndose en piezas clave de la consolidación española en Filipinas. Es precisamente esta condición «fronteriza» la que definía aquellas misiones como eslabones de una iglesia agresiva y militante que fusionaba lo religioso, lo civil y lo político en una sola figura frente al poderío islámico.

Sin embargo, los jesuitas no podían ocuparse de tantos frentes a la vez. Por ello los provinciales de Manila enviaron procuradores a las curias de Roma y Madrid para evaluar la posibilidad de cerrar y/o reducir los efectivos destinados a otras misiones menos productivas, como las islas Marianas, en beneficio de otras mucho más atrayentes, como las de Mindanao y Joló. Uno de ellos, el padre Joseph Calvo, hizo más que eso. Sus propuestas económicas lo convirtieron en uno de los promotores del reformismo ilustrado en las Filipinas ${ }^{101}$.

\footnotetext{
gobernador Gaspar de la Torre, el historiador y jurista Pedro Murillo Velarde y Bravo, SJ, comentaba que «de todo fue gran parte su inacción, desconfiaba de todos, resolvía tarde y ejecutaba con lentitud. Sus costumbres eran de muy cristiano, mejor para tener llaves de un convento que el bastón de las islas. Murió sin dejar ni amigos ni enemigos el año de 1745» (Murillo Velarde, 1752: 49).

98 Carta de fray Juan de San Antonio, ORSA, al rey, Manila, 8 de julio de 1740, AGI, Filipinas, 227, f, 15r.

99 Barrio, 2012: 96-104.

100 Rodríguez García, 1976: 200.

101 Como ya señaló De la Costa (1989: 581), el padre Calvo fue un reformista ilustrado que «offered constructive suggestions for the economic development of the colony which anticipated those of the most enlightened ministers of the Bourbon regime».
} 
Hacia 1738, el padre Calvo escribió varios papeles recomendando el poblamiento de Zamboanga, considerado como un lugar estratégico para la defensa de Mindanao y por ende, de las Filipinas. En uno de ellos describía la isla de Mindanao como una de las que «el grande apóstol San Francisco Javier» había evangelizado, lo que comprometía ineludiblemente a los jesuitas a acudir en defensa de los cristianos que vivían allí. Frente a los jansenistas que acusaban a la Compañía de privilegiar únicamente las sociedades prósperas como el Japón, Siam o China, el proyecto del padre Calvo certificaba el compromiso de los jesuitas con la evangelización de Mindanao y Joló, poniendo freno al avance del islam en el sur de Filipinas.

Sin embargo, el presidio de Zamboanga no era suficiente para contener a los «piratas» joloanos y mindanaos que asolaban las islas Bisayas. La única solución para atajar las incursiones de los «moros» desde el sur, por un lado, y evangelizar unas islas pobladas mayormente por gentiles, por otro, era promover una serie de reformas a través de las cuales se facilitaría «la introducción de la fe entre los moros sin ruido de armas: porque no son aquellos tan tercos en su secta, como los de África, y en tiempos pasados varios se hicieron cristianos» ${ }^{102}$.

La primera, según el parecer del padre Calvo, era fomentar el poblamiento de Mindanao y Joló. El restablecimiento del presidio de Zamboanga no había logrado evitar los ataques piráticos, ni tampoco fomentar la evangelización de la gran isla. La solución pasaba por atraer a un mayor número de colonos españoles. Sin embargo, no era tarea fácil. Teniendo en cuenta que los únicos dispuestos a abandonar las comodidades de Manila eran los soldados y capitanes más pobres, pero «honrados y de méritos», el procurador recomendaba que se repartiese entre ellos diez boletas ${ }^{103}$ de permiso a cada casado, y cuatro a cada soltero, para que conservasen y defendiesen los progresos de la fe católica en aquellas islas. A la postre, dicha medida serviría para desposar a las niñas huérfanas del Colegio Real de Santa Potenciana y de la Hermandad de la Santa Misericordia ${ }^{104}$, en Manila, lo que les resultaba

102 AGI, Filipinas, 227.

103 Como es sabido, la Junta de Repartimiento, fundada en 1604 mediante un Real Decreto de Felipe II, se encargaba del reparto del espacio de carga en el galeón. Dicho espacio se dividía en partes iguales, y a cada parte correspondía una «bala» de tamaño definido. Estas balas, a su vez, eran subdivididas en cuatro piezas, o paquetes, representadas a través de las llamadas boletas, que eran repartidas entre el vecindario. Las boletas eran, pues, certificados de propiedad de cada fardo, pieza o unidad de carga en el buque con autorización (Yuste López, 1984: 20-21; 2007: 55-56).

104 Entre 1589 y 1595 se fundó el Real Colegio de Santa Potenciana. Como señala Francisco Javier Campos y Fernández de Sevilla, «al comienzo era un centro donde se educaba a 
bien difícil, como confesaba el procurador jesuita, porque los más ricos las consideraban inferiores a su condición, los que aspiraban a enriquecerse juzgaban insuficiente los 400 o 500 pesos con que les agraciaban a modo de dote, y a los más pobres no se las concedían porque no se aseguraba que las tratasen con decoro y decencia. Por ese motivo estimaba que los vecinos de Zamboanga eran los candidatos ideales, imaginando un contexto ideal de colonización encabezado por vecinos españoles casados con recursos económicos suficientes para atraer a otros al sur de Filipinas ${ }^{105}$.

Sin embargo, la medida no era suficiente, puesto que el valor de mercado de cada boleta oscilaba alrededor de 40 pesos y para pasar a Zamboanga, según el padre Calvo, era necesario gastar de 300 a 400 pesos, «y si es casado, no le bastarán». La precaria situación del erario público tampoco ayudaba a fomentar la colonización y/o evangelización de la gran isla del sur: «¿Quién, pues, apetecerá pasar a poblar en Zamboanga con tales contrapesos? ¿Quién querrá privarse de las delicias, y conveniencias de Manila, aunque sean cortas, por el interés de 160 pesos, cuando más, pudiendo esperar, que algún día, por el favor de algún poderoso, o por otro medio, podrá conseguir el mismo aumento de boletas, sin menearse de Manila?» ${ }^{106}$.

La segunda reforma consistía en fomentar un comercio triangular entre Manila, Mindanao y Nueva España en base al negocio de la canela. A principios de 1740, el economista don José del Campillo y Cosío (1693-1743) había propuesto una serie de cambios importantes en las políticas de gobierno y comercio de las Indias, basados en un mejor aprovechamiento de la mano de obra y los recursos naturales de las posesiones españolas, incluso aquellas, como las Filipinas, que se encontraban tan alejadas de España. Algunos reformistas, como el padre Calvo, abogaban por aumentar la productividad de los territorios de ultramar para el beneficio de la madre patria.

Los primeros conquistadores de Mindanao ya conocían el valor de la canela ${ }^{107}$. En sus escritos, el padre Calvo reproducía las palabras de su cofrade,

la mujer para ser madre y ama de casa, o profesar en un convento; fue evolucionando en la medida que la sociedad exigió mayor formación en la mujer para poder participar en otras actividades», Campos y Fernández de Sevilla, 2004: 269.

105 Joseph Calvo, de la Compañía de Jesús, Procurador General de la Compañía de Jesús al rey, sin fecha, AGI, Filipinas, 227, f. 9.

106 Joseph Calvo, de la Compañía de Jesús, Procurador General de la Compañía de Jesús al rey, sin fecha, AGI, Filipinas, 227, f. 4.

107 Acompañado del capitán Juan de la Jara y de algunos religiosos de la Compañía de Jesús, como los padres Juan del Campo (1563-1597) y el hermano Gaspar Gómez (15521622), el adelantado Esteban Rodríguez de Figueroa salió de Iloilo (Otón) en febrero de 1596 con 50 barcos, 214 soldados españoles y 1.500 indios para conquistar la gran isla de Minda- 
el padre Edigio Vivar, quien ponderaba los beneficios de canela y las especias que ya había descrito Miguel de Luarca, un encomendero que participó en la primera expedición de los españoles a China (1574-75) y autor del Tratado de las yslas Philipinas ${ }^{108}$. En su opinión, la Corona debería permitir que los primeros cincuenta o cien pobladores de Zamboanga, especialmente los casados, pudieran embarcar hasta doscientos «churlos de canela» 109 sobre el permiso de carga, de modo que compensaran así sus reducidos salarios con un negocio lucrativo ${ }^{110}$. Y no sólo eso. Defendía que para promover la llegada de otros españoles, la Corona debía prohibir que se embarcase la canela de Ceilán en el galeón de Manila, y en lugar favorecer la que se producía en Zamboanga, concediendo a los pobladores de Mindanao el monopolio de su comercio con la Nueva España ${ }^{111}$.

Lo que proponía el padre Calvo era una reforma económica novedosa que a priori permitiría fortalecer la presencia española en Filipinas. En primer lugar, abogaba por la explotación de un producto, la canela, con amplio mercado en el exterior, por parte de los vecinos de Mindanao; y en segundo lugar, impedía la llegada de otros competidores, como los sangleyes, instalados desde un inicio en el parián de Manila y a quienes el procurador jesuita, como muchos otros miembros de su orden, no tenía en gran estima ${ }^{112}$.

nao (abril, 1595-febrero, 1596). A su llegada llevó a cabo la pacificación de la región del río Butúan, en el nordeste, donde se esperaba encontrar canela (De Morga, 2007: 52).

108 Górriz Abella, 2010: 48. Véase también Barrio, 2012: 285.

109 Los churlos eran sacos de lienzo de pita cubiertos con uno de cuero que se utilizaban mayormente para el transporte de la canela, pero también de otros productos, sin que perdieran su virtud o fortaleza (Rodríguez García, 1976: 154).

110 Joseph Calvo, de la Compañia de Jesús, Procurador General de la Compañía de Jesús al rey, sin fecha, AGI, Filipinas, 227, f. 8. Véase también Joseph Calvo, Otro Memorial del mismo Padre Calvo al rey con un informe sobre la conveniencia de conservar el presidio de Zamboanga, Archivo Histórico de la Compañía de Jesús de la Provincia de Toledo, Alcalá de Henares, Madrid (AHCJPT), Filipinas, C-285, documento 7, ff. 33r-66r. Joseph Calvo, Otro Memorial del mismo padre Calvo al Rey proponiendo medidas de que se forma población de españoles en Zamboangan, AHCJPT, Filipinas C-285, Documento 8, ff. 67r-70v. Para una información más general sobre el tema, véase De la Costa, 1989: 542-551.

111 Joseph Calvo, de la Compañia de Jesús, Procurador General de la Compañia de Jesús al rey, sin fecha, AGI, Filipinas, 227, f. 7r.

112 Joseph Calvo, de la Compañía de Jesús, Procurador General de la Compañía de Jesús al rey, sin fecha, AGI, Filipinas, 227, ff. 7r-8r. Oña, 1701: 1375r. Tampoco los dominicos los tenían en mejor estima. Fray Cristóbal Pedroche $(i-1698)$, vicario del Parián y comisario del Santo Oficio, y fray Victorio Riccio Florentín (1621-1685), los responsabilizaron de la ruina espiritual de los españoles y de los nativos de Filipinas, acusándolos de monopolizar el comercio local y regional y de estar únicamente interesados en la plata mexicana, que luego redirigían a China, Memorial de fray Cristóbal Pedroche, OP, con fecha en Hospital de San 
Sin embargo, el gobernador aseguraba que la canela de Mindanao no era de buena calidad. Asimismo, consideraba que

... cuando esa canela empezara a ser rentable lo único que se lograría sería despertar recelos en los vecinos, sobre todo en los holandeses de Batavia, que verían peligrar el comercio de dicho producto de sus factorías, con lo que podrían intentar atacar Zamboanga, o incluso interrumpir el propio comercio del Galeón de Manila, con lo que los gastos serían aún más elevados al tener que hacer flotas de protección ${ }^{113}$.

En 1742, el fiscal del Consejo de Indias aceptó la proposición del padre Calvo de fomentar el traslado de familias cristianas a la isla de Mindanao, pero en cambio rechazó la propuesta de que sus nuevos pobladores pudieran despachar canela directamente a la Nueva España ${ }^{114}$. Las Filipinas, y por ende, Manila, constituían la base de un monopolio comercial con China y el sudeste asiático vía Acapulco que los comerciantes de la Nueva España no querían perder. Desde el comienzo de la Carrera del Pacífico, la Corona dictó leyes que protegían los derechos de los vecinos de Manila en la participación de aquel lucrativo negocio ${ }^{115}$, y por este motivo no quiso enfrentarse con ellos, especialmente a partir de 1740 , cuando la progresiva transformación del régimen de monopolio comercial español había convertido aquel espacio de circulación naval predominantemente ibérico en un «océano internacional» donde tenían lugar intercambios de todo tipo, no sólo económicos, sino sociales y culturales, entre Nueva España y Filipinas ${ }^{116}$.

Tras la guerra de sucesión a la Corona de Austria (1701-13), la presencia de los ingleses se incrementó considerablemente en el Pacífico ${ }^{117}$. Hacia 1739 los conflictos entre la South Sea Company y el gobierno español provocaron una ruptura de las hostilidades con Inglaterra en la llamada guerra de la Oreja de Jenkins o Guerra del Asiento, amenazando, no sólo el proyecto de comercio triangular propuesto por el padre Calvo, sino también el tráfico

Gabriel, Alcaicería Parián de los sangleyes, 10 de junio de 1682, AGI, Filipinas, 228, reproducido en García-Abásolo, 2012: 136-137.

113 Barrio, 2012: 124.

114 Respuesta del Señor Fiscal sobre la oposición que hizo el Diputado de Manila a la población de españoles en el presidio de Zamboanga, concesión de boletas, y otros puntos, 26 de febrero y 16 de abril de 1742, AGI, Filipinas, 227, ff. 1r-26r.

115 Tremmel-Werner, 2015: 132.

116 Matsuda, 2006: 61-763. Bonialian, 2012: 367-448; 2014: 128; 2017: 88-89.

117 Como señaló Laarhoven, desde 1686 los ingleses mantenían relaciones comerciales con los sultanes de Magindanao (Laarhoven, 1989: 149-159). 
regular de los galeones de la ruta Manila-Acapulco ${ }^{118}$. El 20 de junio de 1743 el galeón Nuestra Señora de Covadonga en el que viajaba don Isidro Álvarez de Nava, nombrado gobernador de las islas Marianas, fue apresado por el comandante inglés George Anson (1697-1762) en el cabo del Espíritu Santo, tras un duro combate que le reportó unos beneficios de un millón y medio de pesos ${ }^{119}$. En los últimos cuatro años (1743-47) el comandante Anson había tratado de romper el monopolio comercial de España en sus territorios de ultramar, impidiendo la llegada de galeones con el real situado a las Marianas. En 1744 no se despachó ningún galeón y desde Madrid se ordenó interrumpir totalmente el comercio con la Nueva España por temor a nuevos ataques ingleses ${ }^{120}$. Esta falta de remisiones regulares había sumido a las Filipinas y a las Marianas en una grave crisis económica que el gobernador don Gaspar de la Torre había referido en diversas cartas al zaragozano Pedro Cebrián y Agustín (1687-1752), conde de Fuenclara, Virrey de Nueva España $(1742-46)^{121}$.

En 1745, el padre Calvo escribió dos Memoriales, con fecha en Manila, 22 y 27 de noviembre, en los que recomendaba al rey la urgente reforma del presidio en las Marianas ${ }^{122}$. La dependencia de los poderes civiles de la Compañía de Jesús, así como el escaso fruto obtenido en el archipiélago mariano, había frenado sus planes de enviar misioneros a otros frentes, principalmente en las islas de Mindanao y Joló, donde los jesuitas podían cultivar otros «jar-

118 Rodríguez García, 1976: 159-196. Díaz-Trechuelo López Spínola, 1984: 129-153. Díaz-Trechuelo López-Spínola, 2000: 275.

119 Como señaló Rodríguez García (1976: 176-79), hacía dos años que los galeones de Manila no habían llegado desde Acapulco. Así pues, se esperaba que el galeón de 1743 trajera los reales situados de 1741 y 1742; o sea, mucho dinero.

120 El 20 de mayo de 1742 Ansón capturó el galeón Nuestra Señora de Covadonga a la entrada del estrecho de San Bernardino, a las puertas de Manila, interrumpiéndose la Carrera de la Nueva España (AHCJC, FILPAS-092, 1745-46, f. 74r). Sobre este comandante inglés y las consecuencias de dicha captura hay bastante escrito. Al respecto, véase Rodríguez García, 1976: 152, 174-75. Levésque, 1999: 464-564. García-Abásolo, 2012: 227.

121 El gobernador de las Filipinas, don Gaspar de la Torre, escribió una carta al Virrey de la Nueva España, con fecha en Manila, 22 de agosto de 1745, en la que le comunicaba la inminente llegada de una escuadra inglesa desde la Batavia holandesa a las Filipinas. Las cajas reales se hallaban sin fondos suficientes, por lo que el gobernador solicitaba que enviase situado de los cuatro años anteriores, así como soldados y armas ante la dificultad de mantener las tropas y defender debidamente las islas (AHCJC, FILPAS-092, 1745-46, ff. 78v, 435r). A resultas de ello, el Virrey de la Nueva España escribió al rey, con fecha en Ciudad de México, 14 de marzo de 1746, en la que le comunicaba el miserable estado en el que se encontraban sus vasallos de las islas Filipinas después de la pérdida del patache Nuestra Señora de Covadonga (AHCJC, FILPAS-092, 1745-46, f. 71r).

122 AGI, Filipinas, 299, ff. 93-95v, citado en Lévesque, 1999: 587-595. 
dines» espirituales más productivos entre los musulmanes del sur ${ }^{123}$. Del mismo parecer era el procurador general de Filipinas, el padre Pedro Murillo Velarde, concluyendo

Que para ayuda de gastos a la dicha armadilla y al establecimiento que se discurra necesario para la seguridad de Joló y Mindanao se apliquen como 20.000 pesos que se pueden ahorrar reformando el presidio de Marianas que ya no sólo no es necesario pero es inútil y gravoso al Rey y a los indios ${ }^{124}$.

Si en 1665 el gobernador Sabiniano Manrique de Lara había decidido retirar las fuerzas españolas del sur de Mindanao para concentrarlas en Manila, desamparando a los cristianos que vivían allí, a partir del siglo XVIII los superiores de la orden estaban dispuestos a defender aquella comunidad cristiana a toda costa, aun en detrimento de los escasos chamorros que vivían en las Marianas ${ }^{125}$. Por el contrario, la Corona nunca tuvo la intención de abandonar aquellas islas oceánicas. El 9 de julio de 1739, el gobernador Valdés Tamón ordenó remitir cien familias de tagalos al archipiélago ${ }^{126}$. Y desde 1741 se dictaron Reales Cédulas ordenando su urgente repoblación con el establecimiento de familias tagalas, aunque sin mucho éxito ${ }^{127}$.

No debería sorprendernos, pues, que la Corona no estuviera dispuesta a reducir sus efectivos militares en las islas Marianas ni tampoco a permitir que los jesuitas abandonaran sus puestos, como sugería el procurador Calvo ${ }^{128}$. Así pues, el 5 de octubre de 1745, el fiscal de la secretaria de Estado dictaminó a favor de reforzar en lo posible su presencia en las islas debido principalmente a la presencia inglesa:

... teniendo muy presentes en Manila las razones de conveniencia, y de necesidad para la permanencia de dicho Presidio como escala que es para los galeones del comercio de Filipinas con Nueva España, y adonde llegan a hacer aguada y

123 Sobre la colonización como horticultura espiritual, véase Cañizares-Esguerra, 2008: 239-283.

124 Carta del padre Murillo Velarde, Procurador General de las Filipinas, al Marqués de la Ensenada, sin fecha, RAH, 9/2673/15, f. 1r.

$125 \mathrm{Si}$ en 1737 moraban 2.600 chamorros en las Marianas, en 1741 apenas quedaban 1.816. Dos años después, la cifra ascendió a 2.700 en las parroquias de las islas de Guam (Agat, Merizo, Pago, Umatac e Inarahan), Rota y Saipan.

126 Carta del gobernador Fernando Valdés Tamón, con fecha en Manila, 9 de julio de 1739, en «Testigo de haber sacado expediente sobre repoblación de las Marianas», AGI, Filipinas, 149, exp. 12.

127 AHCJC, FILPAS-093, doc. 27, f. 257. Véase también Ortiz De la Tabla Ducase, 1974: 187.

128 AHCJC, FILPAS-092, f. 51r. 
bastimentarse de lo que necesitan, principalmente de carnes por la abundancia de ganados que producen estas islas, nunca podían pensar ni proponer esta reforma, pues las mismas causas que da el padre Calvo de la disminución de sus naturales, hacen más precisa la guarnición pues esta sirve para mantener el puesto, y la situación de aquellas islas, e impedir se establezcan en ella enemigos de nuestra Corona, lo que sería de gravísimo perjuicio a las islas Filipinas, y a su comercio ${ }^{129}$.

El viaje de circunnavegación del almirante George Anson (1740-44) y el botín del galeón de Manila que consiguió situó el Pacífico en el punto de mira del gobierno británico ${ }^{130}$. Según el parecer de Retana, a mediados del siglo XVIII la situación de las Filipinas era delicada. El situado llegaba con poca regularidad desde la Nueva España ${ }^{131}$. No había dinero para financiar campañas bélicas. Además, los efectivos estaban compuestos de indios, no de españoles, como antaño, y los capitanes capaces de gobernarlos escaseaban. Tampoco se contaba con artillería moderna, ni tampoco con naves, las cuales eran vetustas y achacosas ${ }^{132}$.

En sintonía con el Nuevo Sistema de gobierno económico para la América (1743), publicado por el economista don José del Campillo, el padre Calvo presentó al ministro José de Gálvez (1720-87) un amplio proyecto para el desarrollo económico del archipiélago filipino, con fecha en México, 20 de marzo de 1753, consistente en la reforma de la agricultura, la minería y la lucha contra la «corrupción». No en vano la islas gozaban de abundantes recursos mineros (oro, plata) y agrícolas (azúcar, pimienta, canela, tabaco, nuez moscada) de exportación ${ }^{133}$. Desde un punto de vista constructivo subrayó la necesidad de una cultura de empresa, basada en el comercio, la industria y la iniciativa privada, eliminando en lo posible las barreras aduaneras y el despilfarro ${ }^{134}$. Para ello sugirió la creación de una compañía mercantil a

129 AHCJC, FILPAS-092, f. 54v. Véase también Lévesque, 1999, vol. 13: 596.

130 Frost y Williams, 1997: 410-418.

131 En 1749, el arzobispo de Manila y gobernador interino de Filipinas, fray Juan de Arrechederra (1745-50), escribió al rey Fernando VI lamentando el retraso de dos situados procedentes de Nueva España. Por este motivo, solicitó al Virrey que les enviara el situado con el nuevo gobernador de Filipinas, don Enrique de Olavide y Michelena (en la carpeta se lee: «Consejo, 8 de febrero de $1751=$ al señor Fiscal. Hay rúbrica»), AHCJC, FILPAS-093, ff. $367 \mathrm{r}-368 \mathrm{v}$.

132 Retana, 1897: xxv.

133 Cushner, 1971: 186-87. En su Relación de estas islas Filipinas, dividida en tres partes (Manila, 1654), el padre Combés alababa las riquezas y recursos naturales de la isla de Mindanao (Conbés, 1654).

134 Estas ideas favorables a la libertad mercantil no eran nuevas. El arbitrista portugués, Duarte Gomes Solis (1561/62-ca. 1630), de ascendencia judío-conversa, escribió un Discurso sobre los comercios de las dos Indias (Madrid, 1622) en el que aseguraba que «el comercio 
imagen de las que existían en Inglaterra, Holanda y Francia —el embrión de la futura Real Compañía de Filipinas - que hiciera la ruta directa desde Acapulco a Veracruz rodeando el cabo de Hornos. Sus barcos podrían ahorrar los gastos de equipamiento del galeón de Acapulco, asegurar las comunicaciones entre España y Filipinas y proveer a España de las especias traídas de las islas ${ }^{135}$.

Sin embargo, y a pesar del interés de Felipe V por fomentar el cultivo de la canela en Mindanao, la Casa de Contratación y el Consulado de Cádiz rechazaron su ambicioso proyecto ${ }^{136}$. No es de extrañar, puesto que la presencia española en las islas Marianas, como punto estratégico entre las Filipinas y la Nueva España, tenía que ser reforzada a toda costa ${ }^{137}$.

\section{Conclusiones}

Desde 1645, y especialmente tras la publicación de la III Inocenciana ( 8 de enero de 1649), la última de las tres cartas que el obispo Juan de Palafox y Mendoza (1600-59) dirigió al papa Inocencio X, la Congregación de Propaganda Fide en Roma había puesto en cuestión la postura acomodaticia y tolerante de los jesuitas con respecto a los «ritos chinos y malabares» ${ }^{138}$. Esta controversia, reabierta con las encíclicas de 1742 y 1744, puso al descubierto la imposibilidad material de expandirse hacia Japón y las islas del norte, como había sido el primer objetivo de la Compañía ${ }^{139}$. La única alternativa viable de demostrar el compromiso de los jesuitas con la evangelización de las Filipinas era expandirse hacia las islas de Mindanao y Joló, donde otros «bárbaros fronterizos» — de nuevo, el «moro» infiel, enemigo

y la contratación son más poderosos que las armas», y que si «como caballeros fueran mercaderes, pudieran España y Portugal triunfar» (citado en Molas, 2004: 608-612).

135 García-Abasolo, 2000: 223. Díaz-Trechuelo López Spínola, 1963: 197-201.

136 El 9 de junio de 1742, Felipe V escribió una carta al gobernador don Gaspar de la Torre para que se fomentara su cultivo no solo en Mindanao, sino también en Manila (AGI, Filipinas, 227, citado en Barrio, 2012: 291).

137 No es de extrañar, pues, que el 31 de julio de 1748, el gobernador interino de Filipinas, fray Juan de Arechederra escribiera al rey Fernando VI para informarle de la aplicación de la Real Cédula de 1741 relativa a la repoblación del archipiélago mariano (AHCJC, FILPAS-093, doc. 27, f. 257). Así pues, las islas quedaron definitivamente supeditadas al papel defensivo que debía cumplir frente a la amenaza de las demás potencias coloniales (Brunal-Perry, 2004: 554-555).

138 St. Clair Segurado, 2000a: 40-45.

139 St. Clair Segurado, 2000b: 359. 
de la cruz - amenazaban la consolidación de la cristiandad en el sudeste asiático $^{140}$.

Las actividades diplomáticas de los procuradores ignacianos, como el padre Juan Joseph Calvo y Pedro Murillo Velarde, demuestran la capacidad de maniobra que tenían los jesuitas de la «periferia» con respecto al «centro» romano en términos de estrategia geopolítica ${ }^{141}$. Tras la firma del Tratado de Aquisgrán (1748), los secretarios de estado y de gobierno, como el marqués de Ensenada, ministro de la Marina entre 1743 y 1754, incentivaron la defensa y fortificación de los litorales desde la Florida (iniciadas en 1718 y 1721) hasta Montevideo, así como la modernización de las fuerzas navales para defender un vasto imperio ultramarino (1749) ${ }^{142}$.

Manila, como plaza militar de primera magnitud en el Extremo Oriente, debía protegerse a toda costa, reforzando sus defensas así como los presidios de las islas ${ }^{143}$. En este contexto, el archipiélago de las Marianas se convirtió en un espacio de gran valor geo-estratégico para el imperio español, especialmente tras la transformación del Pacífico en un océano internacional expuesto como nunca a intereses internacionales ${ }^{144}$. Por este motivo, y sin renunciar a la conservación y propagación de la fe cristiana en los reinos de Joló y Tamontaca ${ }^{145}$, la Compañía de Jesús no tuvo más remedio que mantener sus posiciones en las antiguas islas de los «Ladrones», convertida en puntas de lanza y retaguardia frente a los enemigos - ingleses, holandeses - del imperio español hasta su expulsión definitiva en 1769 , siendo sustituida por los agustinos recoletos.

140 Donoso, 2011: 378-384.

141 Županov, 2007: 209.

142 Aunque en 1717 se creó una especie de escuela naval en Cádiz (Academia de Guardias Marinas), las grandes reformas datan del reinado de Fernando VI (1746-1759). En efecto, fue el marqués de la Ensenada, ministro de la Marina entre 1743 y 1754, quien modernizó y fortaleció la marina española con el fin de garantizar la seguridad de sus comunicaciones y proteger así el monopolio comercial con sus colonias de América y el Pacífico sur. Para ello se ocupó del reclutamiento de las tripulaciones y de modernizar el armamento (Parry, 1971). Un programa acertado que, para su total cumplimiento, hubiera requerido de unos recursos de los que la hacienda real no disponía (Stein y Stein, 2002: 304-312).

143 García-Abásolo, 2012: 219-220.

144 Bonialian, 2012: 393-396; 2014: 110.

145 Para más información sobre las actividades diplomáticas de los procuradores jesuitas para evangelizar la gran isla de Mindanao, véase los Memoriales del padre del procurador Pedro de San Cristóbal, SJ, con fecha 7 y 11 de julio de 1747, AHCJC, FILPAS-093, doc. 90 del índice 48, f. 63r; y 14 de agosto de 1747, AHCJC, FILPAS-093, doc. 90 del índice 48-bis, f. 120 r. 
BiBLIOGRAFÍA

Amirell, Stefan y Müller, Leos, "Introduction: Persistent Piracy in World History", S. Amirell y L. Müller (eds.), Persistent Piracy: Maritime Violence and State Formation in Global Historical Perspective, Palgrave, Basingstoke, 2014: 1-23.

Barrio Muñoz, José Ángel del, Vientos de reforma ilustrada en Filipinas. El gobernador Fernando Valdés Tamón (1729-1739), Sevilla, CSIC, 2012.

Beuchot, Mauricio, La querella de la conquista. Una polémica del siglo XVI, México, Siglo XXI, 1992.

Bonialian, Mariano Ardash, El Pacífico hispanoamericano. Política y comercio asiático en el imperio español (1680-1784): la centralidad de lo marginal, México DF, El Colegio de México/Colegio Internacional de Graduados/Entre Espacios, 2012.

Bonialian, Mariano Ardash, "El Pacífico colonial: ¿Una Economía Mundo?”, Angela Schottenhammer (ed.), Tribute, Trade, and Smuggling. Commercial, Scientific and Human Interaction in the Middle Period and Early Modern World, Germany, Harrassowitz Verlag \& Wiesbaden, 2014: 109-132.

Bonialian, Mariano Ardash, "La historia económica del Pacífico en su larga duración. Una revision a las Filipinas y el Pacífico de los ibéricos de Pierre Chaunu", Illes i Imperis, 19 (Barcelona, 2017): 77-99.

Boxer, Charles R., The Christian Century in Japan, 1549-1650, Berkeley \& Los Angeles, University of California Press, 1967.

Brunal-Perry, Omaira, "Las islas Marianas enclave estratégico en el comercio entre México y Filipinas", Leoncio Cabrero Fernández (ed.), España y el Pacifico. Legazpi, Madrid, Sociedad Estatal de Conmemoraciones Culturales, 2004, tomo I: 543-555.

Burrieza Sánchez, Javier, "Los misioneros en la Monarquía”, Teófanes Egido (coord.), Los jesuitas en España y en el mundo hispánico, Madrid, Marcial Pons Historia, 2004: 179-223.

Campos y Fernández de Sevilla, Francisco Javier, "Las órdenes mendicantes en Filipinas: agustinos, franciscanos, dominicos y recoletos", Leoncio Cabrero Fernández (ed.), España y el Pacífico. Legazpi, Madrid, Sociedad Estatal de Conmemoraciones Culturales, 2004, tomo II: 251-284.

Cañizares-Esguerra, Jorge, Católicos y puritanos en la colonización de América, Madrid, Marcial Pons Historia, 2008.

Coello de la Rosa, Alexandre, Jesuits at the Margins: Missions and Missionaries in the Marianas (1768-1769), London \& New York, Routledge, 2016. 
Colín-Pastells, Francisco, SJ, Labor Evangélica de los Obreros de la Compañía de Jesús en las Islas Filipinas. Nueva edición ilustrada con copia de notas y documentos para la crítica de la Historia General de la soberanía de España en Filipinas por el padre Pablo Pastells, SJ., Barcelona, Imprenta y Litografía de Henrich y Cia., 1904, 3 tomos [1656].

Combés, Francisco, SJ (ed.), Historia de Mindanao y Joló. Con la colaboración de Pablo Pastells, SJ, Madrid, Viuda de M. Minuesa de los Ríos, 1897 [1667].

Combés, Francisco, SJ, Relación de estas islas Filipinas (Manila, 1654). Edición a cargo de Alexandre Coello y Jean-Noël Sánchez. Madrid, Polifemo (en prensa, 2020).

Cruikshank, Bruce, "The Moro impact on Samar Island, the Philippines", Philippine Quarterly of Culture and Society, 7:3 (Cebu City, 1979): 141-185.

Cushner, Nicholas P., SJ, Spain in the Philippines. From Conquest to Revolution, Quezon City, Ateneo de Manila University, 1971.

De la Costa, Horacio, SJ, The Jesuits in the Philippines (1581-1768), Cambridge, Massachusetts, Harvard University Press, 1989 [1961].

De Morga, Antonio, Sucesos de las islas Filipinas. Edición crítica y comentada y estudio preliminar de Francisca Perujo, México, Fondo de Cultura Económica, 2007.

Delgado, Juan José, SJ, Historia General Sacroprofana, política y religiosa de las islas del Poniente llamadas Filipinas, Manila, El Eco de Filipinas, 1892 [1751].

Díaz-Trechuelo López-Spínola, María Lourdes, “The Economic Development of the Philippines in the Eighteenth Century", Philippine Studies, 11/2 (Manila, 1963): 195-231.

Díaz-Trechuelo López-Spínola, María Lourdes, "Las Filipinas, en su aislamiento, bajo el continuo acoso", V.V.A.A. (eds.), Historia General de España y América. América en el siglo XVIII. Evolución de los reinos indianos, Madrid, Rialp, 1984: 129-153.

Díaz-Trechuelo López-Spínola, María Lourdes, "Filipinas en el siglo de la Ilustración", Leoncio Cabrero Fernández (ed.), Historia General de Filipinas, Madrid, Ediciones Cultura Hispánica \& AECI, 2000: 249-292.

Diego de Santa Teresa, Fray, ORSA, Historia General de los Religiosos Descalzos del orden de los Ermitaños del Gran Padre, y Doctor de la Iglesia San Agustín, de la Congregación de España, y de las Indias. Tomo Tercero, Barcelona, Imprenta de los Herederos de Juan Pablo \& María Martí, 1743.

Donoso Jiménez, Isaac, El Islam en Filipinas (siglos $X$-XIX), tesis doctoral, Universidad de Alicante, 2011.

Donoso Jiménez, Isaac, Historia cultural de la lengua española en Filipinas. Ayer y hoy, Madrid, Editorial Verbo, 2012. 
Evangelista, Óscar L., "Some Aspects of the History of Islam in Southeast Asia", Peter Gowing (ed.), Understanding Islam and Muslims in the Philippines, Quezon City, New Day Publishers, 1988: 16-25.

Fernández, Pablo, OP, History of the Church in the Philippines (1521-1898), Manila, Navotas Press, 1979.

Frost, Alan y Williams, G., "The Beginnings of Britain's Exploration of the Pacific Ocean", The Mariner's Mirror, 83 (London, 1997): 410-418.

García-Abásolo, Antonio, "Formación de las Indias orientales españolas. Filipinas en el siglo XVI", Leoncio Cabrero Fernández (ed.), Historia General de Filipinas, Madrid, Ediciones Cultura Hispánica \& AECI, 2000: 169-205.

García-Abásolo, Antonio, Murallas de piedra y cañones de seda. Chinos en el imperio español (siglos XVI-XVIII), Córdoba, Universidad de Córdoba, 2012.

García de los Arcos, M. ${ }^{a}$ Fernanda, Estado y clero en las Filipinas del siglo XVIII, México, Universidad Autónoma Metropolitana/Iztapalapa, 1988.

García de los Arcos, M. ${ }^{a}$ Fernanda, “¿Avanzada o periferia? Una visión diacrónica de la situación fronteriza de Filipinas", M. Manchado López y M. Luque Talaván (eds.), Fronteras del mundo hispánico: Filipinas en el contexto de las regiones liminares novohispanas, Córdoba, Servicio de Publicaciones de la Universidad de Córdoba, 2011: 47-69.

Górriz Abella, Jaume, Filipinas antes de Filipinas. El archipiélago de San Lázaro en el siglo XVI, Madrid, Polifemo, 2010.

Gutiérrez, Lucio, Historia de la Iglesia en Filipinas (1565-1900), Madrid, Mapfre, 1992.

Hidalgo Nuchera, Patricio, Las polémicas iglesia-estado en las Filipinas. La posición de la iglesia ante la cobranza de los tributos en las encomiendas sin doctrina y las restituciones a fines del siglo XVI, Córdoba, Servicio de Publicaciones, 1993.

Hidalgo Nuchera, Patricio, “¿Esclavitud o liberación? El fracaso de las actitudes esclavistas de los conquistadores de Filipinas", Revista Complutense de Historia de América, 20 (Madrid, 1994): 61-74.

Hidalgo Nuchera, Patricio, Los primeros de Filipinas. Crónicas de la conquista, Madrid, Miraguano, 1995.

Laarhoven, Ruurdje, The Maguindanao Sultanate in the 17th Century. Triumph of Moro Diplomacy, Quezon City, New Day Publishers, 1989.

Lévesque, Rodrigue, History of the Micronesia. A Collection of Source Documents, Québec, Lévesque Publications, 1999, tomo 13.

Luengo, Pedro, "La fortificación del archipiélago filipino en el siglo XVIII. La defensa integral ante lo local y lo global", Revista de Indias, 77/271 (Madrid, 2017): 727-758. 
Majul, Cesar Adib, Muslims in the Philippines, Diliman, Quezon City, University of the Philippines Press, 1999 [1973].

Martínez Cuesta, Ángel, OAR, Historia de los agustinos recoletos. Vol. I. Desde los orígenes hasta el siglo XIX, Madrid, Institutum Historicum Augustinianorum Recollectorum, 1995.

Matsuda, Matt. K., “AHR Forum. The Pacific”, Karen Wigen (coord. monográfico), "Oceans of History: Introduction", The American Historical Review, 111/3 (Washington, 2006): 758-780.

Molas Ribalta, Pere, "La Compañía como proyecto (siglos XVII-XVIII)", Anuario de Estudios Atlánticos, 50/1 (2004): 607-23.

Murillo Velarde, Pedro, SJ, Historia de la Provincia de Filipinas de la Compañía de Jesús. Segunda Parte que comprehende los progresos de esta provincia desde el año de 1616 hasta el 1716, Manila, Imprenta de Nicolás de la Cruz Bagay, 1749.

Murillo Velarde, Pedro, SJ, Geographia Historica de la América y de las islas adyacentes y tierras árcticas y antárcticas e islas de los mares del Norte y del Sur, Madrid, Imprenta de don Agustín Gordejuela y Sierra, 1752.

Ollé, Manel, "El factor europeo en la dialéctica entre comercio, contrabando y piratería en las costas de China de los siglos XVI y XVII", Angela Schottenhammer (ed.), Tribute, Trade and Smuggling. Commercial, Scientific and Human Interaction in the Middle Period and Early Modern World, Wiesbaden, Harrassowitz Verlag, 2014: 55-76.

Oña, Diego de, SJ, Labor Evangélica. Ministerios apostólicos de los obreros de la Compañia de Jesús. Progresos de las islas Filipinas. Segunda Parte, Manila, ca. 1701.

Oña, Diego de, SJ, Labor Evangélica. Ministerios apostólicos de los obreros de la Compañía de Jesús, (ca. 1701), del Padre Diego de Oña, SJ (1621-1755), editado por Alexandre Coello de la Rosa y Verónica Peña Filiu, Madrid, Sílex, 2019 (en prensa).

Ortiz de la Tabla Ducasse, Javier, El marqués de Ovando, gobernador de Filipinas (1750-1754), Sevilla, Publicaciones de la Escuela de Estudios Hispano-Americanos, 1974.

Parry, John H., Trade and Dominion. The European Overseas Empires in the Eighteenth Century, New York, Praeser, 1971.

Pereña Vicente, Luciano, Teoría de la guerra en Francisco Suárez, Madrid, CSIC, 1954, 2 tomos.

Pereña Vicente, Luciano (ed.), Guerra, intervención, paz internacional, Madrid, Espasa-Calpe, 1956.

Prieto Lucena, Ana M.', Filipinas durante el gobierno de Manrique de Lara (16531663), Sevilla, Escuela de Estudios Hispano Americanos, 1985. 
Retana, Wenceslao E., "Prólogo", Francisco Combés, SJ, Historia de Mindanao y Joló, Madrid, Viuda de M. Minuesa de los Ríos, 1897: I-CXLIV [1667].

Rodríguez Castillo, Nicolás, "Las galeras en Filipinas: guerra, comercio y disciplinamiento social (1580-1650)", Historia Social, 87 (Valencia, 2017): 149-166.

Rodríguez García, Vicente, El gobierno de don Gaspar Antonio de la Torre y Ayala en las islas Filipinas, Granada, Universidad de Granada, 1976.

Saleeby, Najeeb M., Studies in Moro History, Law, and Religion, Beirut, United Publishers, 1973.

Sínodo de Manila de 1582 / Domingo de Salazar, Estudio introductorio, glosa y transcripción de los textos sinodales a cargo de José Luis Porras Camúñez, Madrid, CSIC, 1988.

St. Clair Segurado, Eva M. , Dios y Belial en un mismo altar. Los ritos chinos y malabares en la extinción de la Compañía de Jesús, Alicante, Publicaciones de la Universidad de Alicante, 2000a.

St. Clair Segurado, Eva M. a, "Las misiones jesuíticas del Extremo Oriente en los dictámenes de los obispos españoles (1769-1770)", Revista de Historia Moderna: Anales de la Universidad de Alicante, 18 (Alicante, 2000b): 341-364.

Stein, Stanley J. y Stein, Barbara H., Plata, comercio y guerra. España y América en la formación de la Europa moderna, Madrid, Crítica, 2002 [2000].

Suárez Fernández, Luis, Historia General de España y América. Vol. 9-2, “América en el siglo XVII. Evolución de los reinos indianos”, Madrid, Ediciones Rialp, 1990.

Suárez, Francisco de, SJ, "De bello", Luciano Pereña, Teoría de la guerra en Francisco Suárez, Madrid, CSIC, 1954, tomo II: 1-355.

Torrubia, fray Joseph, OFM, Disertación histórico-política, en que se trata de la extensión del Mahometismo en las Islas Filipinas..., Madrid, Imprenta de Alonso Balvás, 1736.

Tremmel-Werner, Birgit, Spain, China, and Japan in Manila, 1571-1644. Local Comparisons and Global Connections, Amsterdam, Amsterdam University Press, 2015.

Vitoria, Francisco de, OP, Relecciones teológicas. Edición de Jaime Torrubiano Ripoll, Madrid, Librería Religiosa Hernández, 1917.

VV.AA., Historia General de España y América. Tomo XI-1, "América en el siglo XVIII: los primeros Borbones”, Madrid, Ediciones Rialp, 1989.

Warren, James Francis, The Sulu Zone, 1768-1898. The dinamycs of external trade, slavery, and ethnicity in the transformation of a Southeast Asian maritime state, Singapore, Singapore University Press, 1981.

Warren, James Francis, The Sulu Zone. The world capitalist economy and the capitalist imagination, Amsterdam, VU University Press for the Centre for Asian Studies, 1998. 
Warren, James Francis, The global economy and the Sulu Zone: connections, commodities and culture, Quezon City, New Day Publishers, 2000.

Warren, James Francis, Iranun and Balangingi. Globalization, Maritime Raiding and the Birth of Ethnicity, Singapore, Singapore University Press, 2002.

Yuste López, Carmen, El comercio de la Nueva España con Filipinas, 1590-1785, México DF, Instituto Nacional de Antropología e Historia/Departamento de Investigaciones Históricas, UNAM, 1984.

Yuste López, Carmen, Emporios transpacíficos. Comerciantes mexicanos en Manila (1710-1815), México, UNAM, 2007.

Županov, Ines G., "Correnti e contracorrenti. La geopolitica gesuita in Asia (XVI secolo)", P. Broggio, F. Cantù, P. A. Fabre y A. Romano (eds.), I gesuiti ai tempi di Claudio Acquaviva, Strategie politiche, religiose e culturali tra Cinque e Seicento, Brescia, Morcelliana, 2007.

Fecha de recepción: 9 de octubre de 2017.

Fecha de envío de las modificaciones: 28 de febrero de 2018.

Fecha de aceptación: 13 de marzo de 2018.

\section{Geo-strategic and missionary policies in Southern Philippines: the case of Mindanao and Joló (eighteenth century)}

This essay analyses the geo-strategic and missionary policies that promoted the defence of Spanish positions in the Southern Philippines. While the Augustinian Recollects, in charge of the evangelization of the Calamian Islands, denounced the continuous attacks of the "Moors" on the King and the Council of the Indies, and proposed alternatives to the reestablishment of the Zamboanga presidio, the Jesuits wished to maintain it at all costs. The essay also presents the reformist proposition of Juan Joseph Calvo, SJ, General Procurator of the Society of Jesus in the courts of Rome and Madrid, whose effective model of colonization of the island of Mindanao consisted, on the one hand, of gradually dismantling the presidio of Guam in the Mariana Islands, moving its missionaries to the south of the Philippines and, on the other, advocating an economic model of cinnamon exploitation which, although it ultimately failed, sought to promote settlement and strengthen Spanish presence on the great island of the south.

KeY WORDS: Mindanao; Sulu; eighteenth century; Jesuits; Augustinian Recollects; Manila. 